\title{
40. INVENTORY OF BIOSTRATIGRAPHICAL FINDINGS AND PROBLEMS
}

\author{
Maria B. Cita, Institute of Paleontology, University of Milan, Milan, Italy
}

\section{PREFACE}

An effort has been made in the present volume of the Initial Reports of the Deep Sea Drilling Project to present the preliminary findings of the cruise in a coherent package, and at the same time maintain a distinction between (a) descriptive materials, and (b) discussion and interpretation. New data and ideas are pouring out from the Deep Sea Drilling Project at such a great rate that it is becoming increasingly difficult to quickly find in the published volumes generalized and/or specialized information not explicitly treated in individual investigations undertaken by the shipboard scientists and the various shore laboratory groups.

The raison d'etre of this chapter is to attempt to provide a broad cross-reference and summary of the biostratigraphic findings and problems of Leg 13 as a convenience to the reader. Its scope is two-fold. First, the author has attempted to group according to scientific disciplines her observations and those of her shipboard colleagues and numerous other associates. The first part of this chapter serves as a kind of index - a catalogue to guide readers toward paleontological research on the sediments collected during Leg 13. Some of these subjects have been treated previously in the Site Reports in Part I of this volume; others are documented in the Supplementary Reports in Part II of this volume (a few of which provide extensions or confirmations of the work done by the shipboard scientists); and still others are illustrated in much greater detail in the special reports included in Part III of this volume, such as those mostly oriented toward descriptions of floras and faunas. Part IV is oriented more toward solving ecological or biostratigraphic problems.

Some groups of fossils have been investigated carefully. Other groups, which have received little or no investigation, are suitable for future studies.

The second purpose of this chapter, is to comment upon the recovered core material in terms of scientific problems to be solved or at least examined. Many of these observations reflect the shipboard team's confrontation with new facts and ideas which demanded interpretation. Also included are our attempts to anticipate the inquiries of our readers, concerning contemporary scientific dialogues and areas of common interest (i.e. zonations, boundaries, climatic inferences, etc.).

Most of the scientific problems are introduced in the site reports since virtually all the sites were chosen for the purpose of collecting data which could provide answers to existing working hypotheses. As happens often in exploration, new findings - quite unexpected - were made. These are treated in special reports in Parts II and IV of this volume (e.g., the genesis of the evaporites, occurrence of sapropels in the Pliocene, etc.). Occasionally, new informa- tion not reported elsewhere has found its way into the present summary.

Writing the present chapter represented considerable labor for the author and was done at the request of the co-chief scientists, because of a concurrence with their opinion that an effort had to be made to aid the reader's investigations. It is hoped that this effort will be successful and the author asks forgiveness for unwilling mistakes and/or omissions.

\section{INVENTORY OF THE FLORAS AND FAUNAS}

\section{Fossils Belonging to the Plant Kingdom}

\section{Calcareous Nannoplankton}

Calcareous nannofossils, belonging primarily to the Coccolithophorids, are the most abundant fossil group in the 200 cores recovered during Leg 13 of the Deep Sea Drilling Project.

Unlike planktonic foraminifera, they are either not sensitive, or only slightly sensitive to changes in water temperature within the photic zone where they live, or to other ecological changes. Consequently, the calcareous nannoplankton permit a subdivision of the Pleistocene independent from cyclically repeated events, such as climatic fluctuations and stagnant phases induced by glacio-eustatically controlled changes in sea level, etc.

Calcareous nannofossils were investigated in detail during the cruise and after its completion. Lists of fossils and discussions of the stratigraphic successions may be found in all the Site Reports. Chapter 42 by our shipboard paleontologist, H. Stradner, is dedicated to the illustration of calcareous nannofossils from the Mediterranean, including some sixty full page plates of scanning-electron, transmission-electron and optical microscopy photographs.

An additional report by D. Bukry on the calcareous nannofossils is found in Chapter 33 of Part II of this volume. His observations are very interesting, inasmuch as he is broadly familiar with DSDP material from the Atlantic and Pacific Oceans.

Calcareous nannofossils are present in variable amounts, and often represent the most important biogenic component of the sediment. The sedimentary rocks in which they have not been recorded include: the evaporite suite (such as gypsum, anhydrite, halite, etc.) of the late Miocene cored at Sites 124, 134, 132, 125; and the Lower Cretaceous shallow-water limestones of the Hellenic Trench Holes, 127, 127A and 127B.

\section{Silicoflagellates}

Silicoflagellates are commonly associated with other siliceous microfossils such as Radiolaria and diatoms. Siliceous microfossils are generally of rare occurrence in the Mediterranean DSDP cores. 
Silicoflagellates are present in Quaternary sediments of Sites 121 (Alboran Basin), 127 and 128 (Hellenic Trench, Ionian Basin), 129 and 130 (Strabo Trench and Mediterranean Ridge, respectively, both in the Levantine Basin) and in Miocene sediments from Sites 124 and 134 (Balearic Basin).

Contributions in Chapter 34.2 by P. Dumitrica (shipboard paleontologist) deal with the silicoflagellates recorded at Sites 124, 127 and 128, and include a review of the previous knowledge and systematic descriptions of some 16 taxa, one of which (a species) is proposed as new.

\section{Dinoflagellates}

Dinoflagellates are present at Sites 127,128 , and 134 in some of the cores which yield silicoflagellates and other siliceous microfossils. In the Quaternary of the eastern Mediterranean, they are apparently limited to the sapropelitic layers. They are present in marine layers alternating with evaporites in the late Miocene succession penetrated at Site 134.

Unlike silicoflagellates, they have not been subject to special investigations. However, they have been noted in Chapter 35 on the palynology of the sapropels and are listed along with siliceous microfossils (though their skeleton is not siliceous) in the site reports (Chapters 2-15).

\section{Diatoms}

Diatoms are often present in layers which yield other kinds of siliceous skeletons, especially the sapropels. They are listed along with other siliceous microfossils in the Site Reports of Sites 121 (Quaternary), 124 (Miocene), 125 (Miocene), 127 (Quaternary), 128 (Quaternary), 130 (Quaternary), 131 (Quaternary), and 134 (Miocene).

Most of the diatoms recorded are marine. Brackish-water diatoms were recorded by $\mathrm{H}$. Stradner in the Pleistocene of the Nile Cone (see Site Report, Site 131).

A special report on the diatoms of the diatomite recovered from the lowermost core of Site 124 (Core 13), belonging to the evaporite succession of the Upper Miocene, is found in Chapter 34.5 by M. Hajos. This report also considers the Quaternary diatoms recovered at Sites $127,128,130$ and 131 .

\section{Ebridians}

The occurrence of Ebridians in the Mediterranean cores is restricted to diatomitic and sapropelitic marls, which also yield diatoms and other siliceous plankton.

They have been recorded in single cores from Site 124 (evaporitic succession of the Late Miocene), and 127 and 128 (sapropelitic, resedimented layers of the Pleistocene).

They are listed, along with siliceous microfossils, in Chapters 6 and 9. Also, a special report in Chapter 34.4 by P. Dumitrica is dedicated to this group of fossils, little investigated so far. Most of the report concerns the systematic descriptions of some 6 taxa. Two new species and a new genus are proposed.

\section{Chrysomonads}

Chrysomonads are present in a limited number of the sapropel layers rich in siliceous plankton, such as samples from Core 127-5 (Pleistocene) and in the marine fossilif- erous sediments alternating with evaporites in the late Miocene succession cored at Site 124. Some species are listed in Chapter 9, along with the siliceous microfossils.

\section{Hystricosphaerids}

Hystricosphaerids are present in the sand-sized fraction of a very limited number of cores from the Levantine Basin (Site 130) within Pleistocene sediments derived from the Nile Delta which yield a great variety of microfossils. Their presence is indicated in the range charts on planktonic foraminifera (under "various"), for the intervals investigated. They are also considered along with pollen in a report by M. Strick-Rossignol in Chapter 35, where they were noted in the Pleistocene sapropels of Sites 125, 128, 130 , and 131A.

\section{Calcareous Algae and Stromatolites}

Unlike all the fossil groups reviewed so far, calcareous algae are not planktonic, but belong to the sessile benthos. They have been recorded only at Site 127, in the Lower Cretaceous limestones cored in the Hellenic Trench. Their occurrence is one of the indications of a very shallow environment of deposition for these limestones (within the photic zone). They are not listed in the site reports, but are described and illustrated in the special report by W. Maync on the Lower Cretaceous of Site 127 (see Chapter 41.2). The species recorded include Hensonella cylindrica Elliot, Pianella turgida Radoicic, Bacinella irregularis Radoicic, and Boueina (?).

Stromatolites have been recorded in the Late Miocene evaporite successions of Sites 124 (Chapter 6) and 132 (Chapter 13). Some comments concerning their origin are found in Chapter 22 on the petrology and sedimentary structures of the evaporites.

\section{Spores and Pollen}

Spores of terrestrial plants, greater than 100 microns, have been observed in the sand-sized fraction of the sediment in a very limited number of cores from the eastern Mediterranean, in the Pleistocene (125-3-5, 128-3-5, 130-2-3, 130-6, 130-5-2, 131A-1-2, 131A-4-2), Pliocene (Core 125-5-2, 125-127 cm), and Late Miocene (Core 125A $6, \mathrm{CC}$ ). Special palynological investigations have been made in shore-based laboratories (See Chapter 35 by M. StrickRossignol).

In addition to spores and pollen, Phytolitharia, small mineralized bodies belonging to terrestrial plants, were found in some cores from the Late Miocene evaporitic sequence recovered at Site 124 (Balearic Basin) and from the Pleistocene succession at Sites 130 and 131 (Levantine Basin) (see Chapter 34.3 by P. Dumitrica).

\section{Fossils Belonging to the Animal Kingdom}

\section{Foraminifera}

Foraminifera represent one of the most important fossil groups yielded by the 200 cores recovered during Leg 13 of the Deep Sea Drilling Project. They are almost as common as calcareous nannofossils, being absent only from the evaporites (sensu stricto) and basement rocks of the Sardinia slope. 
Benthic foraminifera are in most cores subordinate in number - if not in diversity - to the planktonic species, particularly in the Pliocene-Pleistocene interval which are the best represented in our material.

W. Maync, the shipboard paleontologist whose specialty is this fossil group, has prepared range charts for every site. They are accompanied by comments on the stratigraphic distribution, frequency, etc., in the site reports of Chapters 2 through 15. Two special reports have been prepared in Chapter 41 by W. Maync for Part III of the present volume, one of them pertains to the Lower Cretaceous of Gorringe Bank and, the other to the Lower Cretaceous cored in the Hellenic Trench. The latter includes descriptions and illustrations of some 7 species of benthic foraminifera (mostly with arenaceous test) and 3 species of calcareous algae (see above). The former describes and illustrates 75 species of benthic foraminifera, including 2 new species and 2 new subspecies. Short notes on the benthic foraminifera and their bathymetric significance, from the Quaternary sections continuously cored at Sites 125 and 132 may be found in Chapter 46.

Planktonic foraminifera are abundant in most of the cores investigated. They are absent from the Lower Cretaceous deposits cored at Gorringe Bank and in the Hellenic Trench because of various factors (sedimentation probably occurring below the lysocline in the Atlantic, shallow reefoid deposit in the Ionian Basin). Range charts indicating the occurrence and distribution of planktonic foraminifera are presented in the site reports. Other range charts are attached to Chapter 46, which deals with the Quaternary record of the Tyrrhenian and Ionian Basins. Some taxonomic notes are also included in this chapter, which is mainly devoted to deciphering the succession and chronology of Paleoclimatic events of the Quaternary.

A special report by $\mathrm{M}$. B. Cita is dedicated to Pliocene biostratigraphy, including a description of the new zonation proposed for the Mediterranean deep-sea deposits (see Chapter 47.1). Two new subspecies of foraminifera, one of which is used as zonal marker, are described.

Some selected species of planktonic foraminifera have been used to evaluate the paleoclimatic changes occurring in Pliocene times; a "Globigerionides curve", considered as reflecting changes of temperature in the water masses within the photic zone, could be correlated between three different holes, and the correlation is consistent with zonations based on planktonic foraminifera and calcareous nannofossils (see Chapter 47.3, co-authored with $\mathrm{N}$. Ciaranfi). Isotopic measurements on shells of Orbulina universa demonstrate that the changes observed are unrelated to changes in temperature in the photic zone, but that they are related to oceanographic changes. These arguments are treated by A. Longinelli and M. B. Cita in Chapter 47.4.

\section{Radiolaria}

Radiolaria were found only in a limited number of cores. Their distribution and stratigraphy are discussed in Chapter 34.1 by $\mathrm{P}$. Dumitrica. Radiolaria were noted principally in the Lower Cretaceous marls from Gorringe Bank in the eastern North Atlantic (Site 120), in the Upper Miocene evaporite succession in the Balearic Basin (Site 134), in the resedimented sapropels of the Pleistocene cored in the
Hellenic Trench (Sites 127 and 128), and in some scattered samples of Pleistocene sediment from the Levantine Basin (Sites 129, 130 and 131). The co-occurrence of radiolaria and various kinds of other siliceous and calcareous plankton in sediment oozes interbedded in rock salt at Site 134 points to an episode of open marine conditions during the overall crises of salinity of the Messinian stage of the late Miocene.

\section{Ostracods}

Ostracods have been found in very limited numbers in most of the Plio-Pleistocene cores investigated. Their occurrence (generalized) is recorded in a few of the range charts of planktonic foraminifera. Some identifications of ostracods, made by $\mathrm{H}$. Oertli, are included in the section on benthic foraminifera of the reports on Sites 121 and 129 (Chapters 3 and 10).

Cyprideis pannonica has been recorded in considerable amounts in some samples recovered from Site 129 (Strabo Trench); it is particularly abundant in Core 129 A-2, CC, in an oligotypical assemblage. Stereoscan pictures of this species are illustrated in Plate 1 of this Chapter. Observations by A. Decima concerning this assemblage may be found in Chapter 10.

A short discussion by $\mathrm{R}$. Ciampo on the ostracods recorded in the Pleistocene section continuously cored in the Tyrrhenian Basin may be found in Chapter 46. The report includes a range chart and comments on the bathymetric significance of the species recorded and their stratigraphic range.

Richard H. Benson investigated some cores from the Pliocene of the Tyrrhenian and Ionian basins (Sites 132 and 125) and found in the Tyrrhenian Site deep-living forms characteristic of the upper psychrosphere. A thorough discussion on the depth of the threshold through which they re-immigrated from the Atlantic into the Mediterranean after the "crisis of salinity" of the late Miocene, and on the deep circulation in the Mediterranean in Pliocene times, has been presented in a symposium on the Sedimentation in the Mediterranean held at Heidelberg (1971).

A report by the same author (see Chapter 36.2) concerns the ostracods recorded in various cores at Sites 124, 134, $125,127,129$, and 132. The typical psychrosphaeric species Agrenocythere pliocenica has been recorded in Pliocene sediments both in the Balearic Basin (Site 134) and in the Tyrrhenian Basin (Site 132).

\section{Sponge Spicules}

All the sponge spicules recorded in the cores investigated are siliceous. They are present in great abundance in the resedimented sapropel layers of Pleistocene age recovered from the Hellenic Trench (Sites 127 and 128). In other sapropel layers, as well as in normal pelagic sediments, they are rare or absent. Their occurrence is recorded in the range charts dealing with planktonic foraminifera (under "various"). Some comments on these siliceous microfossils, belonging to organisms leading a sessile benthic life, which occur in layers indicating an euxinic environment, with stagnant waters at the bottom, may be found in the report on Site 128 (Chapter 9). No special investigations have been made of these fossil remains. 


\section{Micrascidites of Tunicates}

Calcareous spinose bodies, known as micrascidites of tunicates, are present in the sand-size fraction of some sediments of Pleistocene age from the Ionian and Levantine basins (Sites 127, 128, and 130). They are also visible in smear slides, and are recorded in the report on calcareous nannoplankton (by H. Stradner) of the various sites, and/or in the range charts on planktonic foraminifera (under "various").

\section{Holothurian Sclerites}

The occurrence of Holothurian sclerites in the sand-size fraction has been noted in a limited number of the samples investigated.

Holothurian sclerites have been recorded mainly in Pleistocene sediments from the Hellenic Trench (Sites 127, 128), from the Nile sediments in the Levantine Basin (Site 130), and from the Tyrrhenian Basin (Site 132). Their occurrence is in most cases recorded in the range charts on planktonic foraminifera. Apparently, they are more abundant in the resedimented sapropel layers. No special investigations have been made of this fossil group for this volume.

\section{Pteropods}

Pteropods have been found in variable amounts in the Pleistocene cores investigated. No special attention was given by the shipboard scientists to this group of calcareous plankton. A special report by Y. Hermann is dedicated to them in Chapter 36.1 .

The occurrence of pteropods is essentially limited to the Pleistocene, where they are much more common in the upper than in the lower part of the section. The greatest abundance of these fossils is recorded in Core 127 A-1, cut directly from the sea floor in the Hellenic Trench at a depth of some 4600 meters, well below what is the present-day compensation depth for aragonite in the Atlantic. On the basis of a rough evaluation, the range distribution of pteropods appears to be climatically controlled. In the Pleistocene section continuously cored in the Tyrrhenian Basin, (see Chapter 46) they are distinctly more abundant in layers rich in volcanic glass than in calcareous oozes.

\section{Gastropods, Pelecypods}

The occurrence of gastropods in the Mediterranean deep-sea cores is limited to coarse-grained layers yielding faunas displaced from a nearshore, shallower environment, as recorded, for instance, in the channel fill of the Valencia Trough and in the Nile Cone clastics. Their occurrence, as well as the occurrence of pelecypods, in the samples investigated is recorded in the range charts of planktonic foraminifera. The pelecypods are present either as shell fragments (usually very thin), or as prodissoconchs.

These fossil remains are in most cases displaced in deep-sea sediments. Sometimes they occur in layers 7 to 8 $\mathrm{mm}$ thick, representing real organogenic sands (see for instance Core 130-3-2, 23-25 cm).

\section{Echinoid Spines}

Echinoid spines are very common in the Mediterranean DSDP cores, though they are never present in abundance.
They occur in purely pelagic sediments as well as in sediments write abundant terrigenous material. Also present are plates, more or less fragmentary, though not as frequent as spines. Their occurrence in the samples investigated is recorded in the range charts on planktonic foraminifera (under "various").

\section{Bryozoa}

Colonies of bryozoa, mostly in fragments, have been recorded in a limited number of the samples investigated. They are co-occurring with other fossil remains displaced from a shallower, nearshore environment by bottom currents (see for instance the Valencia Trough Sites 122 and 123, and Gorringe Bank, Site 120). They have not been investigated in detail, and are recorded in the range charts on planktonic foraminifera (under "various").

Fish Teeth, Scales, Vertebrae, Otoliths

Fossil debris belonging to various types of fishes have not been investigated for the initial cruise report, though they are fairly common and occur in considerable amounts in the sapropels of the eastern Mediterranean. Otoliths and fish teeth are recorded in the range charts of planktonic foraminifera; scales, vertebrae and other remains are recorded as "organic matter." These findings mostly concern the Pliocene/Pleistocene successions.

\section{REVIEW OF THE SCIENTIFIC PROBLEMS}

\section{Preservation and Dissolution}

Generally speaking, the preservation of micro- and nannofossils in the Mediterranean DSDP Cores is very good, as it is in other deep-sea cores. Pyrite crystals adhering to the foraminiferal tests are common and indicate reducing conditions at the sediment-water interface. Pyrite fillings (Figure 1A) are also recorded, though not so commonly, both in the western and eastern Mediterranean. Two species of planktonic foraminifera, Globigerinoides ruber and Globigerina rubescens, often keep their characteristic pink color in the later Pleistocene at some drill sites (see site reports). However, no pink tests have been observed in any of the 220 samples investigated in detail from the Pleistocene of the Tyrrhenian Basin.

Reworked fossils, showing different types of fossilization, have been recorded in the Quaternary fill of the Strabo Trench (Site 129), in the Nile Cone deposits (Site 131), and in the turbidites of the Alboran Basin (Site 121). Displaced benthonic foraminifera often show evidence of erosion. Broken tests are also recorded, as well as fragments and debris of various fossil groups. Pteropods appear to be limited to the later Pleistocene, and their fragile tests are commonly broken.

Siliceous tests completely replaced by pyrite have been recorded from the Lower Cretaceous (Albian) of Gorringe Bank (Cores 120-2 to 120-4). A thin section of a piece of siliceous limestone from Core 8, illustrated in Figure 1B, shows a heavily pyritized radiolarian test. Similarly, pyritized radiolarian assemblages have been recorded in the western Atlantic (Site 105) from Albian and Aptian sediments. This extensive pyritization suggests a reducing environment at the sediment-water interface and stagnant 

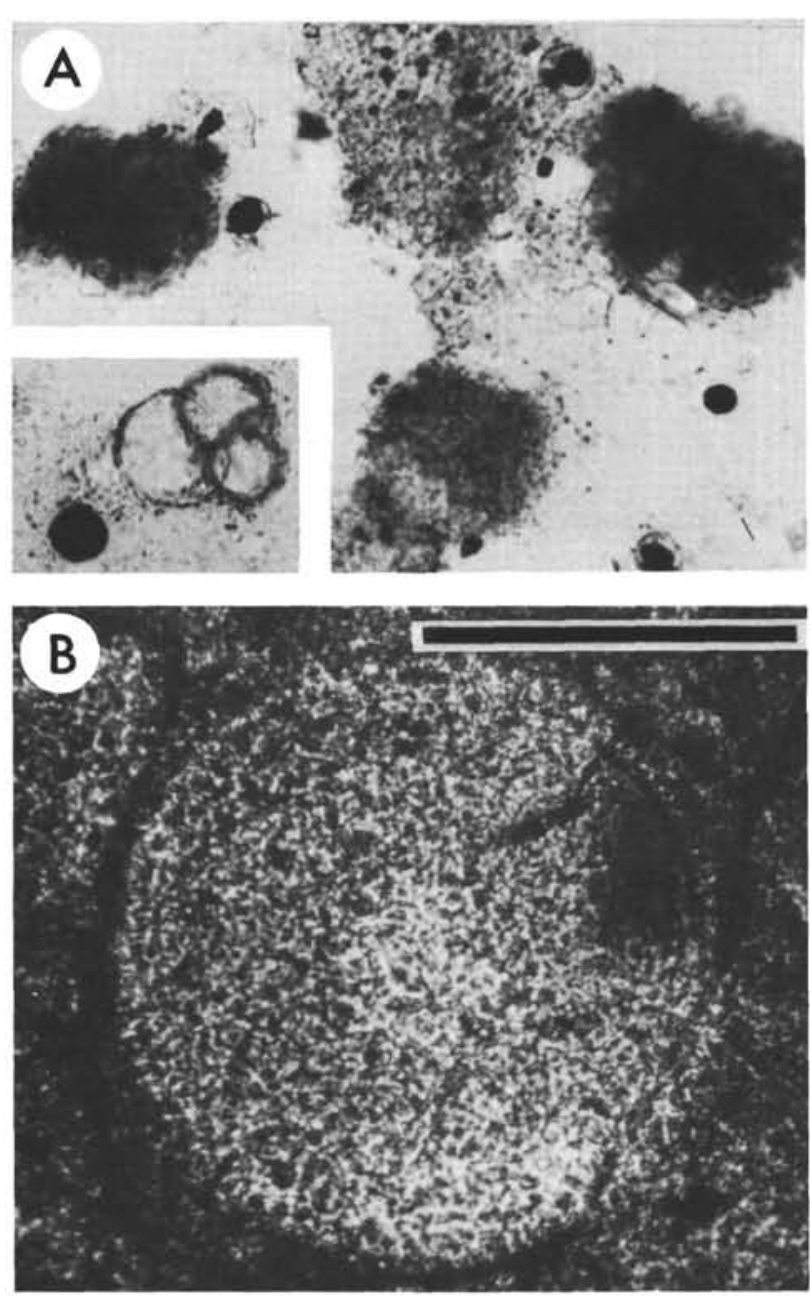

Figure 1. Examples of post-depositional (diagenetic) growth of pyrite. A illustrates pyrite spherules which form initially within the chambers of tests of foraminifera, particularly in layers of sapropel (Core 3 Section 1, $142 \mathrm{~cm}$ of Site 125 -Mediterranean Ridge, Ionian Basin). B illustrates in thin section pyrite replacement of the silica test of a Lower Cretaceous radiolarian (Core 8, Gorringe Bank - Site 120). Scale bar represents 100 microns.

bottom conditions. Lack of burrowing has been observed in these cores (see Summary and Conclusions, Site 120). However, benthic foraminifera have been found in all the Lower Cretaceous cores, with diversified, if not abundant, assemblages (see special report by W. Maync, Chapter 41.1). This indicates that either life conditions were not entirely prohibitive for benthic foraminifera (which are not pyritized), or that they are displaced.

We dislike the latter alternative. Maync, in Chapter 41, describes some seventy-three taxa, including species and subspecies. Twenty-three of these have arenaceous tests, fifty have calcitic tests. None has an aragonitic test, which agrees with a considerable depth of deposition, since aragonite dissolves more rapidly than calcite in water undersaturated with $\mathrm{CaCO}_{3}$. ${ }^{1}$

In terms of species diversity, arenaceous foraminifera represent about 30 per cent of the entire fauna. This proportion does not appear to change considerably in the various intervals investigated. For example, Core 2 , which is particularly rich in pyritized radiolaria, yielded thirty-three foraminiferal species, nine of which have arenaceous tests.

Theyer (1971) recently discussed the bathymetric patterns of calcareous and arenaceous assemblages of benthic foraminifera, and found that predominantly arenaceous assemblages (with $75-100 \%$ arenaceous specimens) are usually more than twice as common as predominantly calcareous assemblages $(0-25 \%$ arenaceous specimens) below 1000 meters in the South Pacific.

A comparison with the data furnished by Theyer is hampered by the fact that, for the Gorringe Bank assemblages, we do not know the numerical composition, but only the number of taxa recorded for each interval investigated.

A level rich in foraminiferal tests, most of which are broken, has been found immediately above the breccia that characterizes the base of the Pliocene succession at Site 132 (Core 21-2, 0-2 cm). The sediment is a nanno-foraminiferal ooze dark red in color, and belongs to the Sphaeroidinellopsis Acme-zone and to the Ceratolithus tricorniculatus Zone.

The stereoscan photographs of Plate 2 (Figs. 1-4) illustrate, at various magnifications, some aspects of the sand-sized fraction, which consists entirely of planktonic foraminiferal tests.

We think that the evident traces of abrasion on the outer surface of the tests and the lack of any evidence of corrosion of the interior indicate that solution is not a factor in the fragmentation recorded here. This abrasion is interpreted by the writer as being related to the catastrophic character of the Pliocene flooding following the "salinity crisis" (see Chapter 47.5).

Foraminiferal tests from horizons underlying the evaporite succession usually have calcite overgrowths suggesting diagenesis in the sediments; this in agreement with their partial lithification.

We looked for evidence of dissolution in the Hellenic Trench, since Sites 127 and 128 were the deepest drilled (water depths $4654 \mathrm{~m}$ and $4640 \mathrm{~m}$, respectively), but we did not find it. No definite lysocline exists in the Mediterranean, which is probably saturated with $\mathrm{CaCO}_{3}$ to its greatest depth because of its present day relatively warm bottom water. Core $127 \mathrm{~A}-1$ cut directly from the sea floor was extremely rich in pteropods, which possess an aragonitic test. This means that even aragonite, which is known to dissolve more readily than calcite, can be preserved here.

However, in Pliocene times, the situation was very different from the present day, and a deep oceanic type circulation existed between the Atlantic and the Mediterranean (see the discussion of hiatuses, non-deposition, etc. later in this Chapter 47.4).

\footnotetext{
${ }^{1}$ The absence of Epistomina, which commonly is represented by a number of species in the Lower Cretaceous, and possesses an aragonitic test, is pointed out by W. Maync.
} 
When investigating a number of samples from Site 132 for biostratigraphic purposes, evidence of slight dissolution was seen in Core 19, Sections 3 and 4. This interval belongs to the lower part of the Globorotalia margaritae margaritae Lineage-zone, and immediately overlies the Sphaeroidinellopsis Acme-zone of the basal Pliocene. The sediment is represented by nanno-ooze of light olive gray color, and in the visual core description Sections 3 and 4 are described as containing "scarce visible forams."

Traces of solution are visible on the foraminiferal shells in the form of holes, enlarged pores, and traces of corrosion of the outer wall. Also, a number of shell fragments are present. In order to check these qualitative observations, the same method of measurement used by Cita (1971b) has been followed, with some minor modifications.

Figure 2 contains 6 diagrams concerning: (a) the weight of the fraction greater than 63 microns, (b) the faunal diversity, as represented by the number of taxa identified, (c) the plankton/benthos ratio, (d) the percentage of fragmented tests (weight ratio) versus entire tests, measured on the fraction greater than 173 microns, (e) the number of specimens (tests) per gram of fraction greater than 63 microns, and (f) the average weight of 100 foraminiferal tests, measured at six levels from Sections 1 to 4 , Core 19.

Sections 3 and 4, in which evidence of dissolution was present, gave the lowest grain-size fractions; these fractions entirely consist of foraminiferal shells. Sections 3 and 4 also yielded a (slightly) lower number of taxa and gave a lower plankton/benthos ratio with respect to Sections 1 and 2, which do not show evidence of dissolution.

These results compare well with the studies of the Pliocene section of DSDP, Site 12 (Cape Verde, northeastern Atlantic), where the effects of dissolution are quite visible in the lower part of the Pliocene (see Cita, 1971a, 1971b).

The percentage of fragmented tests varies from near 10 per cent (in Sections 1 and 2) to 20 to 30 per cent and more in Sections 3 and 4. These values are much lower than those measured in the sediment column of Cape Verde to which reference is made; however, there is a difficulty in comparing our results as the fraction considered is not the same $(>63$ microns at Site $12,>173 \mu$ at Site 132).

Diagrams (e) and (f) of Figure 2 show that there is a negative correlation between the number of specimens per gram of the sediment fraction and the average weight of 100 specimens. This suggests that dissolution is not responsible for the observed changes in the average weight, but that the changes are related to the average dimensions of the foraminiferal shells (the weight of 100 small specimens is much smaller than the weight of 100 large specimens).

The average weight of 100 foraminiferal shells compares well with that found at Site $12 \mathrm{C}$ and 12D in the same stratigraphic interval if we exclude the levels of Site $12 \mathrm{C}$ showing evidence of strong dissolution.

On the whole, the measurements made confirm the

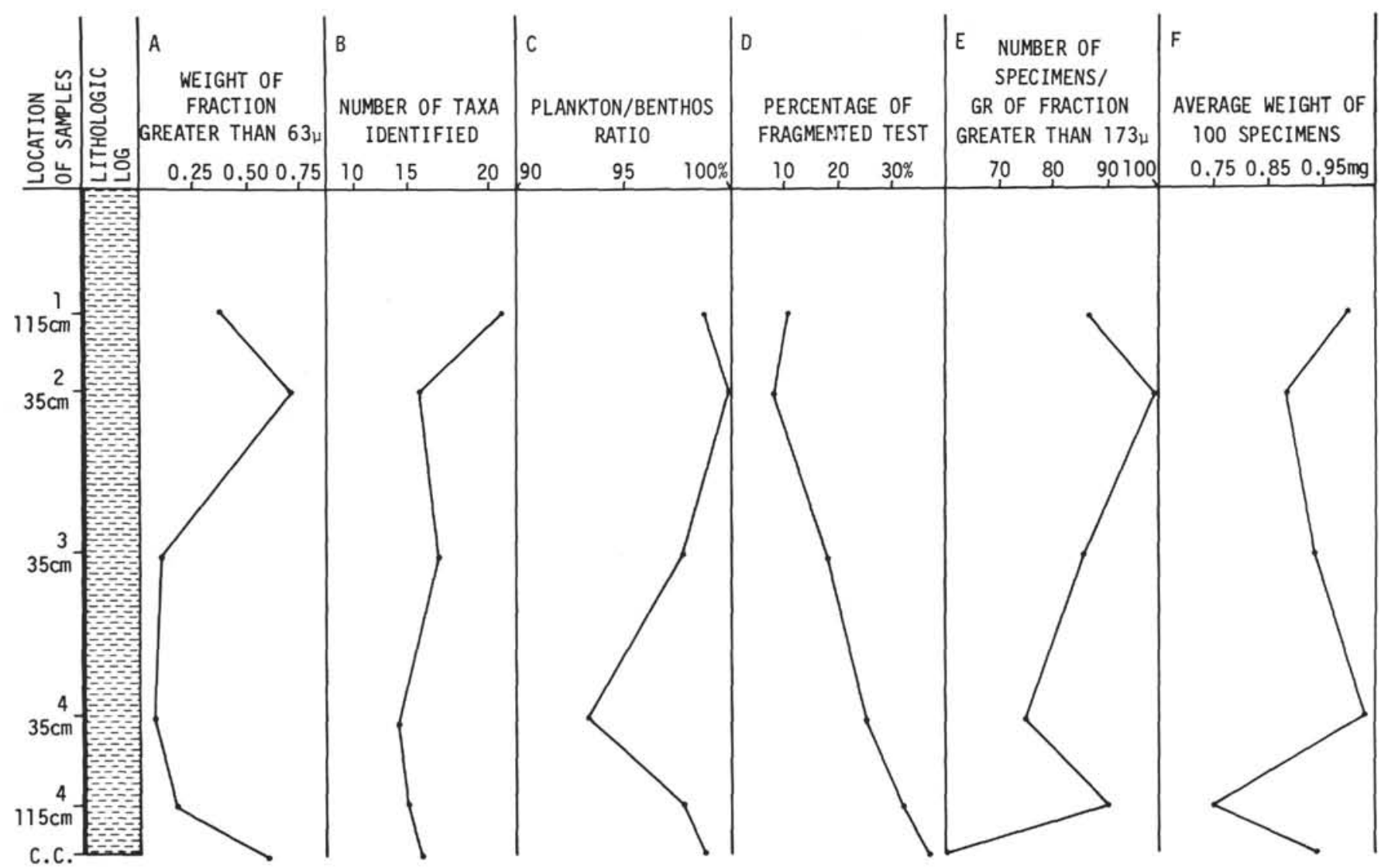

Figure 2. Evidence correlative with partial solution ("oligolytic" facies) in Core 19, Sections 1 through 4 of Site 132 Tyrrhenian Basin. The age of the sediment is Lower Pliocene. 
qualitative observations previously discussed and the evidence of slight dissolution. ${ }^{2}$ With reference to the dissolution facies defined by Hsü and Andrews (in Maxwell, et al, 1970), the sediments under discussion may be considered of eolytic to oligolytic facies.

The criterion used to distinguish between these two facies, according to the authors mentioned, is the foraminiferal content which is $>10$ per cent in the eolytic facies, $<10$ per cent in the oligolytic facies. In the smear summary of Core 19, Site 132, a foraminiferal content of 5 per cent is indicated. The suggested bathymetry related to the carbonate compensation depth is 500 to 1500 meters above the CCD for the eolytic facies, and 200 to 500 meters above for the oligolytic facies.

A dissolution cycle has been recognized in the Atlantic which lasted from about Eocene times to the end of the Miocene (DSDP Legs 1 to 4 ). It has been related to an important circulation system existing between the Pacific and Atlantic oceans during periods when they were connected (Cita, 1971a). A rapid change in the dissolution facies has been observed in the lower Pliocene of the North Atlantic (Cita, 1971b). At that time the passage between the Atlantic and the Mediterranean was much wider and deeper than at present, thus allowing important exchanges of water masses at depth by oceanic-type geostrophic currents. It is, therefore, quite reasonable that slight dissolution occurred in the Mediterranean, originated by the deep and cold Atlantic waters which, unlike those filling the present day Mediterranean, were not saturated with $\mathrm{CaCO}_{3}$. For a further discussion of this point see Chapter 47.4.

Some evidence of solution at depth is also found at Site 120 (Gorringe Bank); however, this evidence is based primarily on the following negative observations: (a) absence of planktonic foraminifera in a stratigraphic interval where they are commonly recorded (Albian to Barremian), and (b) absence of nannoconids below Core 4 . Cores 5 to 7 (Core 8 contained basement rock) are devoid of these calcareous nannofossils which are usually very well represented in the Barremian.

Atlantic DSDP cores have shown that planktonic foraminifera are much more susceptible to solution than benthonic forms (see Cita, 1971a, p. 254; Theyer, 1971). Also, nannoconids are probably more susceptible to solution that coccoliths, which in turn are more susceptible than discoasters (see Cita, op. cit., p. 263).

Colom (1967, p. 306) considered the absence of "rosetta-like" nannoconids in the Balearic-Subbetic Zone to be an indication of a greater depth of deposition, as opposed to the Mexican Lower Cretaceous limestones described by Trejo (1960) which yielded rich assemblages. Going further, we may suggest that the absence of nannoconids in the Lower Cretaceous of Gorringe Bank is an indication that sedimentation occurred at such a depth that important post-depositional dissolution occurred.

Colom wrote the following about the possibility that nannoconids dissolve (op. cit., p. 306) "... En ce qui concerne la dissolution des tests des Globigérines, on pourra

\footnotetext{
${ }^{2}$ Between 260 and 863 foraminiferal shells have been considered for each interval, with an average count of about 500 .
}

objecter que les Nannoconus sont également calcaires et, cependent, se recontrent en grand nombre dans ces dépots. Mais, dans certains niveaux ils manquent ou ils sont très rares, alors le ciment de ces roches devient une vraie boue de grains de calcite. Représententils, ces niveaux, les limites d'une fase avancée de leur destruction?" Colom considers the Lower Cretaceous succession of the Balearic-Subbetic Zone to be the deepest deposits of the entire Mesozoic cycle.

\section{Reworking and Displacement of Fossils}

Although the sediment types recorded in the Mediterranean DSDP cores are numerous, two of them are most prevalent: (a) pelagic oozes, consisting mainly of nannofossils and foraminifera, associated with various amounts of clay minerals; and (b) terrigenous deposits, in part of turbidity current origin. Reworking plays a fairly important role in the latter; it is absent or very limited in the former.

Among the various fossil groups investigated, nannofossils are those most subject to reworking. Some reworking is often recorded also in purely pelagic sediments, where the foraminiferal assemblages are entirely autochthonous.

Significant reworking in the nannofossil assemblages has been noticed especially in the Mio-Pliocene successions of turbidite layers penetrated at Site 121 (Alboran Basin), in the Nile Cone Site 131, and in the lower part of the Pleistocene succession penetrated in the Levantine Basin at Site 130. Reworked forms include Cretaceous and Eocene species.

At both Sites 121 and 131 reworking of planktonic foraminifera, including Upper Cretaceous species, has also been observed. However, most of the samples investigated yielded penecontemporaneous assemblages.

The amount of reworking was surprisingly low (even in terms of nannofossils) in the Pleistocene filling of the Hellenic Trench (Sites 127, 128). Considering the high rate of sedimentation (in excess of $26 \mathrm{~cm} / 10^{3} \mathrm{y}$ in both locations) considerable terrigenous influx was expected which we thought would contain an accumulation of fossil species derived from older sediments. Instead, the recovered material contains primarily fossils which were generally penecontemporaneous with their primitive burial.

Extended reworking is suggested as a possible alternative explanation for the abnormal stratigraphic succession recorded at Site 129, in the Levantine Basin (foot of the Strabo Mountain). Reference is made to discussions in Chapter 10 and to the discussion of tectonic mixing in the present chapter, where the argument is treated more exhaustively.

Displacement of faunas from nearshore, shallow environments into the abyssal plains, where some of our drilling sites were located, was noted on many occasions. Displaced fossils include benthic foraminifera, pelecypods, gastropods, bryozoa, and others. Some of these observations are also plotted in the range charts of planktonic foraminifera for Sites 121, 122, 123, 124, 130, 130A and 131 .

In addition, spores of terrestrial plants were observed in the Pleistocene terrigenous sediments derived from the Nile (Sites 130, 131).

Benthic foraminifera considered displaced include Ammonia beccarii, Elphidium spp., Asterigerina, Amphis- 
tegina, Discorbis, some Miliolids (excluding Pyrgo spp. and Articulina tubulosa, which are deep-water forms). Their displacement is deduced from the difference between the actual water depth and the bathymetric range known for the species under consideration. In some cases the difference may be 2000 meters or more. Some of the displaced tests, mostly the largest ones, show signs of abrasion.

Specimens of Amphistegina lessonii, exceeding $3 \mathrm{~mm}$ in size, were found in abundance in some Pliocene samples from Site 123 (Valencia Ridge).

Hyalinea baltica, a characteristic fossil of the marine Quaternary, has been found at only two locations (Sites 121 and 122), and in only a few of the hundreds of Pleistocene samples investigated. This fossil is a "northern guest", which penetrated the Mediterranean at the beginning of the ice ages (?); its first occurrence in the section of Le Castella, Calabria, has been taken as a marker point for the Plio/Pleistocene boundary (see INQUA Congress, 1965).

At Site 121 (Alboran Basin), the water depth is only about 1119 meters, and we surmise that Hyalinea baltica may possibly be autochthonous there since it ranges from -60 to about -1000 meters in the present day Mediterranean. It is surely allochthonous in the channel-fill of the Valencia Trough (Site 122, water depth $2156 \mathrm{~m}$ ), where large specimens are recorded in a coarse layer rich in terrigenous components and in other kinds of fossil debris indicating a shallow-water environment.

\section{Winnowing, Sorting}

Evidence of winnowing and sorting was often noted in the Neogene sections penetrated in both the western and eastern Mediterranean. These observations are limited to intervals where sedimentation was fed by bottom currents. In pelagic sediments the faunal assemblages do not show evidence of size sorting; in these sediments, small and large foraminiferal tests co-occur, either representing different ontogenetic stages of the same species, or belonging to discrete taxa, with different average size.

Bottom current influence on sedimentation does not necessarily imply the activity of turbidity currents. In some instances, winnowing is more likely the result of particleby-particle removal from the sea bed by geostrophic currents.

Selection of sediment of a particular grain size or shape may be accentuated, and millimeter- or centimeter-thick layers of planktonic foraminiferal tests, uniform in size, may result. Such layers are described as "foraminiferal sands" and generally consist of foraminiferal shells up to 80 per cent in bulk volume as visually estimated in smear slides (see, for instance, Site 126 Cores 1 and 2 and Site 128 Cores 3-11) (Figure 3). These abundances are much greater than those recorded in purely pelagic sediments, where they usually range from 3 per cent to 10 per cent (deduced from weight ratios), unless conditions of particularly high productivity prevailed (see the discussion on productivity later in this chapter).

The most typical examples of winnowed and/or sorted faunal assemblages have been recorded in the abyssal plain deposits fed by the Nile in the Levantine Basin (Sites 130, 131), in the sediments filling the Hellenic Trench, in the
Ionian Basin (Sites 127, 128), and in the sediment fill of the cleft in the Mediterranean Ridge (Site 126).

The provenance of the Hellenic Trench is primarily the inner wall (landward side) of the trench sediments, and consists of organogenic marl oozes (nannofossils and subordinately, foraminifera) with terrigenous contributions (sand, clay minerals). Discrete layers of foraminiferal sand are present in some sapropelitic layers cored in the Hellenic Trench (e.g., DSDP Core 128-3-5, 68-70 cm). They are interpreted as the product of winnowing, related to eddies above the sea floor which removed the finer particles as soon as the plankton fall-out occurred without modifying the stagnant condition of the basin.

Sorting by size may result in a faunal diversity less than normal. In fifteen samples investigated from the Pleistocene section penetrated at Site 127, least faunal diversity was recorded in intervals which show the clearest evidence of sorting. Further details on the subject may be found in Chapter 9.

Winnowing and sorting by size may result in a selection of planktonic foraminifera giving false paleoclimatic indications. In fact, most, if not all, the cold-water indicators are small sized, such as Globigerina pachyderma and Globorotalia scitula, while the warm-water species are distinctly larger in size, as Orbulina universa, Globorotalia truncatulinoides, Hastigerina spp., Globigerinoides conglobatus, G. sacculifer, and others. At Sites 126 and 127, warm-water species occur near the base of a graded bed, cold-water species at the top. Since the bed itself is the result of instantaneous deposition, we cannot think of important climatic changes occurring in such a short time, and cannot use the faunal evidence for it.

\section{Dwarfed Faunas and Specialized Faunas}

Dwarfed foraminiferal faunas and oligotypical faunas have been found in the evaporitic sequence of the upper Miocene in both the western and the eastern Mediterranean.

Sedimentary control and sorting by size may result in the accumulation of small-sized skeletons in discrete layers. However, this has nothing to do with "dwarfness" as controlled by ecologic factors, such as low or high salinity, or other abnormal chemical and physical conditions. Thus, we do not consider as "dwarfed" the small-sized assemblages so commonly found in the Pleistocene filling of the Hellenic Trench, which are resedimented and sorted by size; nor do we consider as "dwarfed" the small-sized assemblages occurring in the coldest intervals of the glacial Quaternary, where cold species, which are usually smallsized, are present in high percentages. "Dwarfness" is a response by individuals to unfavorable life conditions which interrupt their growth earlier than in normal, open marine conditions.

Unfortunately, the life cycle of planktonic foraminifera is unknown, or at least no published reports on the subject are known to the writer. We may guess that the life span may be longer than usual in abnormal conditions, as demonstrated for the benthic foraminifer Ammonia beccarii in the classical experiments by Bradshaw (1961).

Dwarfness has been observed both in planktonic and in benthic foraminifera, but our observations are very preliminary and tentative, because we had just a few samples 
to examine. For instance, we found some evidence of dwarfed faunas in the pyritic marls overlying the evaporite beds at Sites 124, 125, 132 and 134; yet we did not find such evidence in the sandy intercalation recorded between two beds of salt rock at Site 134 (fossiliferous bed in Core 9). Here the assemblages are poor, but the specimens recorded are almost normal in size.

We do not want to place too much stress on this point, nor to speculate too extensively on this meager evidence; however, in the light of our desiccation model for evaporite deposition (see Chapter 43) it seems that -

1) when the inflow of Atlantic water was very limited in duration, as is the case for the sandy layer intercalated in the halite banks, at Site 134, faunas are scanty, but almost normal in size and these faunas all probably immigrated directly from the Atlantic;

2) when the inflow of Atlantic water lasted for a long time, dwarfness is observed. This is probably the result of generations of foraminifera born inside the Mediterranean, in ecologically unfavorable conditions.

Dwarfed assemblages of planktonic foraminifera and specialized assemblages are well known from literature on the marine beds alternating with the evaporites in the Messinian of Italy, including the neostratotype Messinian (see d'Onofrio, 1966).

The most specialized fauna we recorded during Leg 13 was that yielded by the core catcher sample of Core 2, Site 129A, in the Strabo Trench. The sediment is a pyritic marl, fairly rich in fossils, including coccoliths and related forms (Miocene in age, with normal assemblages); planktonic foraminifera, distinctly dwarfed; and two species of benthic organisms, the ostracod Cyprideis pannonica (see Plate 2, Figures 2 and 3) and the foraminifer Ammonia beccarii tepida. Both species are very common, representing a highly specialized assemblage.

Almost identical assemblages are found above the Messinian evaporite of the Gessoso Solfifera series of Sicily (Decima, personal communication) and are considered characteristic of the Upper Messinian. They indicate salinities ranging from 20 to 30 per cent. It is to be noted that late Miocene evaporites with dwarfed faunas are recorded in the eastern Mediterranean as well, both in Crete (Freudenthal, 1969) and in Cyprus (Turner, 1971).

\section{Stagnation}

The Mediterranean underwent periods of stagnation at different times after the Miocene. This resulted in the deposition of particular sediment types characterized by a high content of organic carbon, iron sulfides in various amounts, and by peculiar faunal and floral assemblages.

Diatomaceous marls, often characterized by a high content of organic matter (sapropel), are known from the basal part of the Messinian ("Tripoli" member of the Formazione Gessoso-Solfifera, see Ogniben, 1957). We did not core deep enough through the evaporites to reach this level, but in the lowermost core (15) recovered from Site 124 in the Balearic Basin we found a few centimeter-thick layers of black, sapropelitic diatomite indicating stagnant conditions at the sea bottom. The organogenic content of this layer has been analyzed and the results of the study by Hajos (Chapter 34.5, this volume) show a mixture of fresh

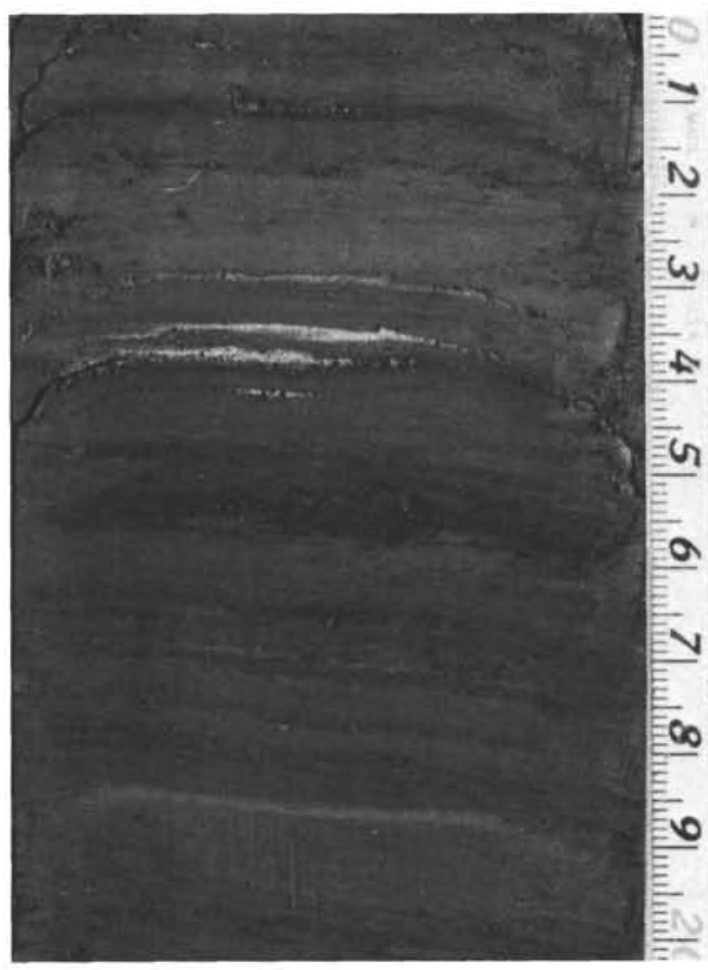

Figure 3. Illustration of millimetric - thin foraminiferal sand layers in finely laminated sapropel horizons of Pleistocene age from Core 3, Section $6,14 \mathrm{~cm}$ at Site 128 - Hellenic Trench. Scale is in centimeters.

water, brackish water, and marine forms. The most abundent diatoms belong to the genus Dimaegramma, a marine littoral form.

Some indication of stagnant water masses at the bottom is also found in the Middle Miocene penetrated in the Levantine Basin (Site 129). Though only a few cores were taken there, and core recovery was poor, an impression of abnormal sedimentation was obtained because of the complete lack of signs of benthic life. There were no benthic foraminifera, no ostracods, no echinoid spines, etc., but only planktonic foraminifera and pyrite crystals, in the sand-fraction. Similar findings are also recorded from the Ionian Basin (Serravallian of Site 126).

The writer had the occasion to discuss this problem with Dr. J. P. Beckmann, who has wide experience in the eastern Mediterranean. Beckmann noted that in Egypt the Middle Miocene successions show evidence of stagnant conditions, also leading locally to deposition of evaporites which are Middle Miocene in age (Kerdany, 1968).

The most important evidence of stagnation occurs higher in the section, in the Upper Pliocene and especially in the Pleistocene, and is limited to the eastern Mediterranean.

Olausson (1961) interpreted the sapropelitic cycles as being related to the communications between the eastern Mediterranean and the Black Sea and controlled by glacio-eustatically induced chages in the sea level. Reference is made to the report on the Quaternary record of the Ionian Basin (see Chapter 46) where the argument is treated in some detail. 
Stagnant cycles, resulting in the deposition of centimeter- to decimeter-thick sapropel layers, have been revealed by piston-coring since the Swedish Deep Sea Expedition of 1947-1948. They occur in sequences of pelagic sediment which range in age from recent post-glacial times, back over $1,000,000$ years (lower sapropelitic interval of the Lower Pleistocene) and to about $2.4 \mathrm{my}$ (Upper Pliocene, Globigerinoides obliquus extremus Zone (foraminiferal), Discoaster pentaradiatus Zone (nannofossil)).

Sapropel layers indicating stagnation have been recorded in the Pliocene only at Site 125A (Core 2, Section 2); and in the Pleistocene, at the following locations and intervals: Site 125 (Ionian Basin), Cores 1 and 3; Site 126 (Ionian Basin), Core 1; Site 127 (Ionian Basin), Cores 5, 13, and 14; Site 128 (Ionian Basin), Cores 3 and 8; Site 130 (Levantine Basin) Cores 1 and 2; and Site 130A (Levantine Basin), Core 1.

Only at Sites 125 and $130 \mathrm{~A}$ is the sediment purely pelagic. At other locations sediment accumulation resulted from a combination of organogenic fall-out of mineralized tests of micro- and nannoplankton and of terrigenous clastics, mostly clay minerals. A considerable part of the organogenic component is not autochthonous but has been redeposited by geostrophic bottom currents or by turbidity currents. Investigations of the fossil content of sapropelitic layers made for the initial report are by no means exhaustive for any of the various fossil groups; therefore, the following observations must be considered preliminary.

The fossil content of the sapropelitic layers includes the following groups (order of presentation does not imply abundance):

1) Coccoliths - those which apparently are not affected by changes induced by stagnation at the bottom and/or by changes in salinity near the surface.

2) Radiolaria - present occasionally. They are practically absent (at least, they are not recorded) at Sites 125 and 126. They are present at some intervals at Sites 127 and 128 , but absent in most samples.

3) Silicoflagellates and ebridians - commonly associated with radiolaria.

4) Diatoms - associated with other siliceous plankton (see 3), but not invariably.

5) Pteropods - recorded in variable amounts in some sapropelitic layers, sometimes redeposited.

6) Spores of terrestrial plants - as recorded for instance in Core 125 A, 6, CC; evidently redeposited.

7) Otoliths - common, and sometimes fairly abundant. Unlike the groups previously analysed, these fossil debris are of nektonic, not planktonic derivation.

8) Holothurian sclerites, micrascidites of tunicates and sponge spicules - all of these fossils belong to organisms leading a benthic life, which are not expected to survive in an euxinic environment. However, they have only been recorded in the sapropelitic layers of the Hellenic Trench (Sites 127 and 128, to which reference is made), not in the pelagic sequence of the Mediterranean Ridge (Site 125). The first two groups have a calcitic skeleton; sponge spicules are always siliceous, and are very common at some intervals; reference is made to "paleoenvironment" of Site 128 (Chapter 9) for a discussion of the productivity of siliceous plankton and organisms during periods of deglaciation.

The problem is to determine if these mineral particles belong to bottom-living organisms autochthonous in the sapropels, or if they are derived? If the latter assumption is accepted; where are they from? Why do we find them only, or primarily, in the sapropelitic layers? Other benthic fossils (entire tests) as foraminifera, or ostracods, are practically absent in the sapropelitic layers.

This inventory has a number of puzzling aspects. One obtains the impression that the sapropelitic layers, especially the resedimented ones, are for some reasons an ideal trap for many types of microfossils seldom recorded in normal pelagic sediments. However, conclusions based on such a limited number of scattered observations do not seem to be warranted.

9) Planktonic foraminifera - generally present in all samples. They have been investigated in some detail in the Plio-Pleistocene section penetrated at Sites 125 and 125A.

In Core 1 of Site 125 , three sapropelitic layers were noted. They belong to the glacial Quaternary and are characterized by important climatic fluctuations, with marked cold intervals. The sapropels here have been found associated with foraminiferal faunas indicating temperatewarm or warm-temperate conditions. They are, however, less diverse than normal associations contained in layers indicating a well-ventilated environment. Globigerina bulloides, G. eggeri and Globigerinoides ruber are among the best represented taxa.

Three additional sapropelitic layers have also been recorded in Core 3 of Site 125. They belong to the so-called preglacial Quaternary (see discussion in Chapter 46), which is characterized by fluctuating climatic conditions, but without marked cold intervals. A peculiar characteristic of these lower Pleistocene sapropelitic cycles is a very high productivity of planktonic foraminifera (see discussion of productivity later in this chapter). Unlike the glacial Quaternary sapropels, the preglacial ones are not dominated by the Globigerina bulloides - G. eggeri - Globigerinoides ruber assemblages, but seem to be characterized by an Orbulina universa - Globigerinoides conglobatus Hastigerina siphonifera assemblage. Further investigations are needed to test this observation.

The sapropelitic layers recorded in the Upper Pliocene belong to the lower part of the "green climatic interval" of Cita and Ciaranfi (1971), an interval indicating fluctuating climatic changes, cyclically repeated. These sapropelitic layers, as well as the Lower Pleistocene ones, are interpreted as related to glacio-eustatically controlled changes in the sea level deriving from glaciation(s) and deglaciation(s) occurring far away from the Mediterranean area.

The first (Oldest) evidence of extended glaciation in the North Atlantic Ocean dates back to about 3 million years ago (Berggren, personal communication). It is documented by the presence of ice-rafted debris above sediment rich in tropical faunas and containing nannofossil assemblages of the Discoaster asymmetricus and Diseoaster surculus zones (see Perch-Nielsen, 1972).

A comparable nannofossil assemblage is also found in Core 4 of Hole 125A and Core 7 of Hole 125 within an interval identified here as having cold faunas (i.e., the 
"brown climatic episode" described in Chapter 47.3. It is quite reasonable to expect that this first (oldest?) extended glaciation recorded in the North Atlantic Ocean would be accompanied by eustatic fluctuations of the world sea level. It is interesting, therefore, to note that not only do the Mediterranean sediments record the climatic change, but also that the presence of oxygen-starved lithologies indicates that shallow sills separating the eastern and western basins were effective, even during the Pliocene, in constricting the communication of water masses at times of the glacio-eustatic depressions of sea level.

Two additional points concerning the behavior of planktonic foraminifera during the periods of stagnation will be briefly discussed. First, unlike the foraminiferal assemblages at Site 125, those recorded from the sapropelitic intervals cored at Sites 127 and 128 are extremely variable both in number and in size. Some of the samples investigated (see, for instance Core 128-3-5, 17-19 cm) were almost completely devoid of foraminifera, or yielded only a limited number of small-sized specimens (Core 128-3-5, $80-82 \mathrm{~cm}$ ). Other samples (for instance Core 128-3-6, 89-90 $\mathrm{cm}$ ) consist of foraminiferal sands, representing a millimetric accumulation of large-sized, well-sorted and highly diversified foraminiferal tests. We believe, accordingly, that redeposition by some process of sea floor current activity plays an essential role in the distribution of planktonic foraminiferal tests for the above mentioned occurrences. The second point concerning behavior of planktonic foraminifera is that stagnation of bottom waters in late Pliocene-Pleistocene times, according to the model proposed (for the glacial Pleistocene) by Olausson (1961) and Ryan (1971), is restricted to basins of the eastern Mediterranean.

In the western Mediterranean, important oceanic-type geostrophic bottom currents of a permanent nature (see discussion of productivity later in this chapter) apparently have prevented this area from having a similar history of stagnation. However, we did detect some limited indications of restricted marine conditions (euxinic type) in the Pleistocene of the Tyrrhenian Basin (Site 132). This is documented by both the occurrence of pyrite crystals and organic matter in some abundance and by a faunal diversity less than usual, with a certain dominance of Orbulina universa, Globigerinoides conglobatus and Hastigerina siphonifera.

On the basis of detailed correlations of climatic curves, the levels containing evidence of reduced conditions in the Tyrrhenian Basin could be shown to be synchronous with fully developed stagnant conditions in the Ionian and Levantine basins. In fact, the lower part of Section 5, Core 6 of Site 132, which was particularly rich in pyrite and showed the above noted lack of faunal diversity, corresponds to one of the best developed and thickest sapropel intervals at Site 125 (i.e. Core 3, Section 4, 35-60 cm). It has been deduced that this horizon records such an overwhelming density stratification that even the western basins shared in the oxygen depletion of the locallygenerated bottom water masses.

\section{Productivity}

The present day productivity of the Mediterranean is known to be very low. In fact, the Mediterranean is considered ". . . the most impoverished large body of water known" (Ryan in Fairbridge, 1966, p. 493) because active exchange of statified water masses through the relatively shallow Straits of Gibraltar effectively flushes back out of the Mediterranean any of the original nutrients that may once have entered from the west in the already depleted surface layer of the North Atlantic. However, different lines of evidence lead us to postulate that in past times (Pliocene and lower Pleistocene) the sill separating the Mediterranean Sea from the Atlantic Ocean was not as shallow as it is at present.

Our findings of numerous submarine hiatuses in prePleistocene strata (see discussion under Hiatuses, nondeposition, etc. later in this chapter) demonstrate that a deep geostrophic circulation of considerably greater intensity than that which is found today was active at least in the western Mediterranean during the past. This deduction agrees well with the presence of psychrospheric ostracods at Sites 132 and 134 which require much colder bottom water than that measured at present (see Chapter 36.1).

Since communication of bottom waters over a deep sill at Gibraltar would not have led to a nutrient depletion, it seems reasonable to speculate that organic productivity would have been greatest during times of least restricted exchange between the Mediterranean and the Atlantic.

According to Olausson (in Fairbridge 1966, p. 496), currents in the straits of Tunisia and Sicily, and probably also in the Strait of Gibraltar, were reversed during times of deglaciation, when the surface salinity of the eastern Mediterranean was lower than that of Atlantic water because of the large amount of meltwater received from the Black Sea and other nearby source areas. It is possible that this important change in the superficial circulation also resulted in an increase of productivity.

Evidence of increased productivity in the Pleistocene has been noted in the Alboran Site 121 and in the Hellenic Trench Sites 127 and 128. In both cases the sediment is a calcareous nannofossil ooze with an abundance of terrigenous material, mainly clay minerals. Foraminifera represent only a minor component of the sediment.

The observed average rate of sedimentation at these sites is very high, exceeding $20 \mathrm{~cm} / 10^{3} \mathrm{y}$. Because reworking apparently plays a minor role in the net accumulation (see section on nannoplankton biostratigraphy in Chapters 3 and 9), we may speculate that there must have been an abnormally high productivity of nannoplankton. Since coccoliths live in the photic zone, we would expect that they should be sensitive to changes introduced in the surface water by reversal of the current system to and from the Atlantic.

A quantitative evaluation of the productivity in planktonic foraminifera has been attempted for the Pleistocene succession continuously cored at Site 125 , in the Ionian Basin. The site is located on the crest of the Mediterranean Ridge and the sediments are purely pelagic. No reworking or distinct winnowing has been noticed in the 185 samples investigated in detail. Weight ratios of $5 \mathrm{cc}$ samples were calculated (percentage of sand-sized fraction $>63 \mu$ versus the entire dry weight) and are reported in Figure 5 of 
Chapter 46. Since the sand-sized fraction consists entirely of foraminiferal tests, the weight ratio may be used as a means of evaluating the production of planktonic foraminifera. Benthic foraminifera are extremely rare (generally less than $1 \%$ in number), as are other fossil remains, and sand-size detrital components are absent.

The average weight ratio of the sand-sized fraction (= planktonic foraminiferal shells) versus the total sediment of 100 samples from Section 2 of Core 1 to Section 1, of Core 4 , Site 125 , is 6.88 per cent. Important changes in the recorded values were observed, however, in the various intervals.

We have excluded from our countings, samples taken from sapropel layers. The weight ratios here often exceed 1.0 per cent, but since the sand-sized fraction also contains organic.matter, siliceous sponge spicules, etc., we could not reliably use these values to evaluate the productivity of planktonic foraminifera.

Of 100 measurements made and shown in Figure 4, seventeen are in excess of 10 per cent. Most of these latter belong to Core 3 , which contains three discrete sapropel layers, among which the thickest was recovered from this site. Three exceptionally high values were recorded; all of them from Sections 4 and 5, Core 3. They are in excess of 20 per cent, with a maximum value of 26.07 per cent (Sample 125-3-5, 109-111 cm). The highest values (in excess of $26 \%$ and of $23 \%$, respectively) have been found in layers immediately underlying sapropelitic layers of the lower Pleistocene sapropelitic interval (Pseudoemiliania lacunosa Zone (nannofossil)). The foraminiferal faunas of these levels are particularly rich, though not necessarily highly diversified, and indicate eutrophic conditions. Therefore, we may conclude that during periods of ventilation and oxygenation, alternating with stagnant periods, the life conditions were particularly favorable to planktonic foraminifera (shells of Orbulina universa and of Globigerinoides conglobatus approaching $1 \mathrm{~mm}$ in size are recorded in this interval).

The interval in which the highest productivity has been recorded belongs to the lower Pleistocene, a long time before the onset of glaciation in the circum-Mediterranean area. It is interesting to note that this was a period during which a deep, oceanic-type circulation is proposed to have existed between the Atlantic Ocean and the Mediterranean Sea.

Unlike the lower sapropelitic interval with high apparent productivity, the upper one, recorded in Sections 3 and 4 of Core 1 and belonging to the Gephyrocapsa oceanica Zone (nannofossil) of the glacial Pleistocene, is not characterized by high weight ratios. Samples from the upper sapropelitic interval belong to the I set of data of Figure 4 and to the upper part of the II set, which are characterized by the lowest average values of weight ratio (= lowest average productivity of planktonic foraminifera).

\section{Sedimentation Rates}

The rate of sedimentation was calculated whenever we were able to locate in a given section at least two well-defined datum planes, correlated to the paleomagnetic stratigraphy. The datum planes we used, from top to bottom, are as follows:
1) Extinction horizon of Discoaster brouweri within the Olduvai event of the Matuyama Reversed epoch $(\approx 1.85 \mathrm{my})$,

2) Extinction horizon of Sphaeroidinellopsis spp., corresponding to the Kaena event of the Gauss Normal epoch $(\approx 2.9 \mathrm{my})$,

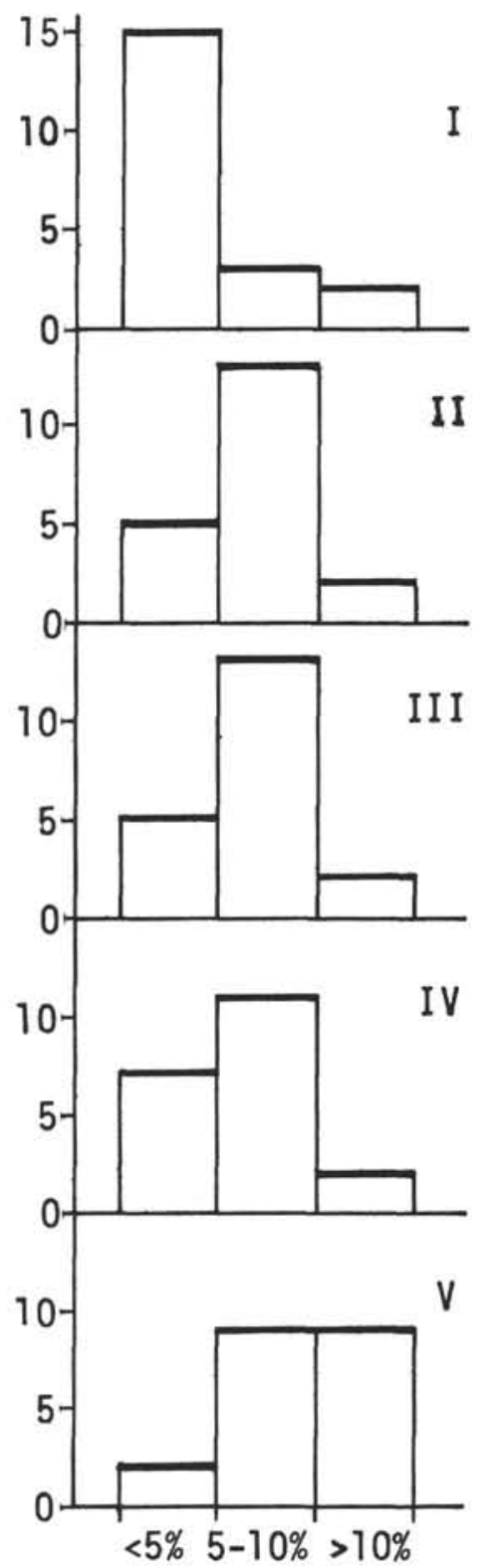

Figure 4. Histograms of weight ratios (\%) showing relative proportions of foraminiferal tests $>63 \mu$ as compared to bulk weight of dry sediment for 100 samples from the Pleistacene section of Site 125 - Ionian Basin. The greater ratios (e.g., the largest ratios are in the column to the right) correspond to an inferred increase in productivity. The I set of 20 data is from Core 1-1 (132 $\mathrm{cm})$ to Core $1-3(101 \mathrm{~cm})$; the II set of 20 data is from Core 1-3 (116 cm) to Core 2-2 (122 cm); the III set of 20 data is from Core 2-2 (138 cm) to Core 3-2 $(22 \mathrm{~cm})$; and the IV set of 20 data is from Core $3-2(34 \mathrm{~cm})$ to Core $3-4(93 \mathrm{~cm})$; and the $V$ set of 20 data is from Core $3-4(105 \mathrm{~cm})$ to Core $4-1(91 \mathrm{~cm})$. 
3) Extinction horizon of Globorotalia margaritae, corresponding to the Gilbert-Gauss epoch boundary ( $\approx 3.32 \mathrm{my}$ ).

Reference is made to Hays et al. (1969) and to Berggren (1971) for a discussion of these datum planes and to Chapter 47.2 for their identification in the cored sequences of Sites 125 and 132 .

In cases of discontinuous coring, if we were not able to locate a given datum plane within a core but could guess its presence between two consecutive cores, we took the half-way position as the location of the datum plane. In the case of biostratigraphic events not related to the paleomagnetic stratigraphy, we evaluated the sedimentation rate by using the time scale of Berggren (1971), slightly modified according to discussions found in Chapter 47.4. When we were even unable to locate any definite datum plane in a section (as for instance in Sites 120, 126, 129, $130,131)$, our evaluation of the sedimentation rates was even more cautious.

Our best calculations concern the sections continuously cored in the Tyrrhenian Basin (Site 132) and in the Ionian Basin (Site 125, 125A). Both sites were selected for continuous coring at locations characterized by pelagic sedimentation - a small rise west of the Tyrrhenian Abyssal Plain and the crest of the Mediterranean Ridge. Since the accumulation of sediments at both sites was uninterrupted and the faunal assemblages are very rich, we were able to identify all the datum planes previously discussed. The resulting rates of sedimentation were fairly uniform, averaging $3.3 \mathrm{~cm} / 10^{3} \mathrm{y}$ for the site in the Tyrrhenian Basin and $2.5 \mathrm{~cm} / 10^{3} \mathrm{y}$ for the site on the Mediterranean Ridge. The difference between the two may be accounted for by the smaller size of the Tyrrhenian Basin and also by the more important volcanic contribution there.

Sedimentation rates between 5 and 8 to $9 \mathrm{~cm} / 10^{3}$ y have been calculated for the late Neogene marine sections penetrated in the western Mediterranean, at sites on the Balearic Rise and Balearic Abyssal Plain. The high rate of sedimentation (about $20 \mathrm{~cm} / 10^{3} \mathrm{y}$ ) recorded in the Pleistocene sections of the Alboran Basin (Site 121) and of the Hellenic Trench (Sites 127, 128) has already been accounted for by stimulated organic productivity (see prior discussion of productivity in this chapter).

The highest sedimentation rates recorded in the Mediterranean are from the Pleistocene of the Levantine Basin in terrigenous sediments fed by the Nile. A rate up to 100 $\mathrm{cm} / 10^{3} \mathrm{y}$ is estimated for the pre-glacial Pleistocene recovered at Site 130, where coarse sediments of a proximal turbidite facies were encountered. A rate in excess of 30 $\mathrm{cm} / 10^{3} \mathrm{y}$ has been calculated for the glacial Pleistocene (terrigenous) section penetrated on the Nile Cone.

The lowest values of the rate of sediment accumulation for the drilling leg was recorded in the eastern North Atlantic at Gorringe Bank, Site 120 where a markedly thin sedimentary succession was recovered. The sedimentation rate could be evaluated with a certain degree of accuracy only for the Lower Cretaceous (Barremian to Albian) interval, where it turned out to be less than $0.5 \mathrm{~cm} / 10^{3} \mathrm{y}$.

The sedimentation rate of the evaporitic sequence could not be calculated. Our deepest penetration, 65 meters, into the evaporites was at Site 124. Though no definite biostratigraphic datum plane was found to which reference could be made for correlation, we do believe that the rate of sedimentation of the evaporites is very high, particularly since the average thickness of the evaporites in the western Mediterranean (Balearic Basin) is estimated by all the geophysicists with whom the writer was able to communicate, at some hundreds of meters, if not more, without considering any thickening related to salt tectonics. The reader is referred to Chapter 37 for documentation of the seismic evidence on the thickness of the evaporites beneath the central abyssal plains, which corresponds well to that known from central Sicily. Here, the stratigraphic succession for the late Miocene-Pliocene interval is so similar to that found in our deep-sea wells (see Chapter 44.1) that we feel some confidence in extrapolating into the lower part of the Messinian, which we were not able to core directly.

As for the time duration of the evaporitic epoch, we know that in the lower Messinian (i.e., late Miocene, post-Tortonian times) just prior to the time when the sedimentation first gives evidence of restricted marine conditions, there is adequate evidence ${ }^{3}$ of the occurrence of Globorotalia plesiotumida, the zonal marker of Zone N 17 of Blow's (1969) zonal scheme (Cita et al., 1965). This species has also been recorded from strata assigned to the Messinian in northern Algeria (Mazzola, 1971), in central Italy (Colalongo, 1970) and by us, in deep Mediterranean holes.

Discussions are presented in Chapter 47.5 which concern the level of the base of Zone N 17 at equatorial Pacific DSDP drill sites. The arguments presented there, which involve an application of the paleomagnetic time scale, suggest that a maximum age of $7.5 \mathrm{my}$ can be assigned to this datum. Because the entire Messinian stage is considered to be within this zone (Colalongo, 1970; Catalano and Sprovieri, 1971), and its lowermost part is preevaporitic, we believe (based on extrapolated rates of sedimentation) that the actual salinity crises did not commence until sometime around $7 \mathrm{my}$. Thus we are left with only about $1.6 \mathrm{my}$ for its duration until the terminal flooding which reinitiated permanent marine conditions in the lowermost Pliocene (5.4 my).

If we consider a thickness of 800 meters for the evaporitic sequence at Site 124 (see discussion in Chapter 6) we can then calculate a rate of deposition approaching $50 \mathrm{~cm} / 10^{3} \mathrm{y}$ for this facies - a value considerably higher by an order of magnitude than that of the open marine post-evaporitic sedimentation at the same site.

\section{Hiatuses, Non-Deposition, Submarine Erosion, Unconformities}

Upon many occasions during Leg 13 evidence of hiatuses or of submarine erosion was provided by the biostratigraphic investigations. In some instances, a gap in sedimentation can be inferred from gross sedimentary features alone, although generally this is not the case. However, when gaps and hiatuses are present in the recovered cores,

\footnotetext{
${ }^{3}$ This stratigraphic interval is referred to as the Sahelian by Ruggieri et al. (1969), followed by his school (see Catalano and Sprovieri, $1969,1971)$. This use of the stage-name Sahelian, however, is not accepted by scientists familiar with the Sahelian stratotype (see discussion in Catalano and Sprovieri, 1971).
} 
there is usually complementary evidence in continuous reflection profiles from that region. In fact, it turns out that quite a few of the seismic reflecting horizons present in the sedimentary blanket which covers the floor of the Mediterranean basins owe their existence to acoustic impedence contrasts at erosional surfaces.

The most prominent gap in sedimentation is found at the Miocene/Pliocene boundary. We cored this boundary at three sites, 134 in the Balearic Basin, 132 in the Tyrrhenian Basin, and 125A in the Ionian Basin. In other locations (122 in the Valencia Trough, 124 in the Balearic Basin, and 129 in the Levantine Basin) cores were taken above and below this boundary. In each case the facies change across the boundary was correlatable to acoustic Reflector M.

Reference is made to Chapter 47 of this volume for the interpretation of paleogeographic conditions at the end of the Miocene and at the beginning of the Pliocene (i.e., sudden, deep-sea transgression related to the collapse of the "dam" separating the Atlantic Ocean from the desiccated Mediterranean basins) as well as for a summary of the biostratigraphic succession found at the sites where recovery was complete across this horizon.

Gaps in sedimentation related primarily to submarine erosion have been found both in the western and in the eastern Mediterranean (Sites 121, 122, 123, 124, 126, 134). Sorne of them are related to channel cutting in Quaternary times, probably by canyon-following turbidity currents. This is certainly the case for the Valencia Trough Sites 122 and 123 , where a gravel layer represents the base of the Quaternary; all the features of a channel-fill are present, including displaced, size-sorted shallow-water benthic foraminifera.

At both Sites 122 and 123 the Pliocene/Pleistocene boundary is recognizable within a core or in two adjacent cores (cut back to back), and the contact between the Upper Pliocene and Pleistocene layers is unconformable.

Biostratigraphic resolution is extremely high for the Plio-Pleistocene interval. In fact, six foraminiferal zones and seven nannofossil zones distinguished in the deep-sea Mediterranean Pliocene deposits allow us to recognize time intervals as small as 500,000 years or less. The same is true also for the Quaternary, as far as the nannofossils are concerned. Thus, we were able to document the lack of the topmost part of the Pliocene and of the lower part of the Pleistocene there, corresponding to a time gap of about 1 million years.

Also, at Site 126 in the Ionian Basin, it seems reasonable to suggest some sort of sediment removal by turbidity currents, along the cleft in the Mediterranean Ridge. However, at this location core recovery was very poor, and we have no direct evidence of a major erosional contact in any of the cores investigated.

The interpretation of the probable gaps occurring in the Miocene/Pliocene succession penetrated at Site 121 in the Alboran Basin is more problematic, essentially because we could not recognize any clear-cut erosional surfaces in the badly disturbed cores. However, lack of the topmost part of the Miocene is suggested by both the biostratigraphic succession and the seismic record; in fact, this truncated sequence may even be related to subaerial erosion during periods of low sea level in the latest part of the Miocene (Chumakov, 1971).
Evidence of nondeposition, accompanied by a hardground has been found in the Balearic Basin (Site 134E, Sidewall Core 1, $199 \mathrm{~m}$ below bottom). It is probably pure luck that we were able to obtain, by means of the first experimental sidewall core taken during the project, the fossiliferous, mineralized crusts which make up this hardground, as well as the unconsolidated sediments above and below. It occurs precisely at the level of a distinct reflecting horizon which can be traced for hundreds of kilometers in the Balearic Basin, and which produced a clear drilling break when penetrated.

The sediment contained in the sidewall core is an unconsolidated nannofossil-foraminiferal ooze, yielding a number of fragments of thin, fossiliferous, mineralized crusts, less than $1 \mathrm{~mm}$ thick, and some detrital material accompanied by a number of planktonic foraminifera. Several of the foraminiferal tests show iron spots and are more or less deeply mineralized.

Two fossil assemblages, characterized by mutually exclusive species indicating Upper Pliocene (Globigerinoides obliquus extremus Zone [foraminiferal], Discoaster surculus Zone [nannofossil]) and Pleistocene age, co-occur in the fraction greater than 63 microns obtained from processing several cubic centimeters of sediment. The mutually exclusive species obviously come from discrete layers immediately underlying and overlying the hardground(s), and have apparently been mixed by the coring operation.

Plates 3 and 4 illustrate some aspects of this unconformable succession. Figures 1-3, Plate 3, illustrate single tests of planktonic foraminifera of Pleistocene age. Species of Pliocene foraminifera (Globigerinoides obliquus extremus and Globorotalia crassaformis) from this sample are illustrated in Plate 4.

Figures 4-6, Plate 3 and Figures 2-3, Plate 4, document, at various magnifications, some of the mineralized, fossiliferous crusts, and clearly show their surface textures as well as the occurrence of planktonic foraminifera incorporated within them, either as tests, or as casts.

Figure 1, Plate 4, illustrates a thin section of an artificial agglomerate obtained from the sand-size fraction of the sediment from the core under discussion. Reference is made to the figure captions for detailed descriptions.

Prof. Alberto Castellarin (Institute of Geology of the University of Bologna), who kindly prepared and analysed the thin section, commented as follows: "The mineralized crusts (fragments) essentially consist of iron hydroxides; most of the organogenic components included in the crusts are almost completely substituted by the iron hydroxide. Also present in the sediment are mineral grains of different kinds, including plagioclase, (?) orthoclase, quartz, chert, small fragments of probable metamorphic rocks, etc. These components are sometimes alterated and/or substituted along their borders by the iron hydroxides." it is interesting to note that no phosphatic components (collophane) were optically recognizable, which actually differentiates the present hardground from those studied by Prof. Castellarin in the Southern Alps.

A number of hardgrounds are known from the fossil record of the Mediterranean area (see Malaroda, 1962; Castellarin, 1962; Premoli-Silva and Luterbacher, 1966; and Jenkyns, 1970). Those with which the present author is 
familiar (see Cita, 1965) are the products of nondeposition, eventually accompanied by submarine erosion, in pelagic sediments indicating a considerable depth of deposition (Scaglia formation). The sediments both above and below the mineralized crust(s) (often in the form of roots) are always consolidated, unlike those at Site 134E.

Generally speaking, hardgrounds are only a few centimeters thick and may represent time spans as long as some millions of years (Holmes, 1965). In cases of condensed sedimentation, some meters of rock may be the sedimentary expression of tens of millions of years, as is the case for the "Rosso ammonitico" formation. The most favorable situation for the creation of extended hardgrounds, or of a series of hardgrounds, is that of a structural "high" in a stable area, accompanied by a deep oceanic type circulation which removes, particle-by-particle, the pelagic, mostly organogenic sediments falling to the bottom (shells of planktonic foraminifera, shells of ammonites, mineralized plates of planktonic algae, etc.). Under these circumstances, manganese and/or iron oxides may precipitate, thus creating the thin mineral crusts similar to those found in Sidewall Core 1, Site 134E.

At this particular location in the Balearic Basin, two conditions differ from the classical case discussed above, namely, (a) we are not on a structural "high", but at the edge of an abyssal plain, and (b) the period of nondeposition is relatively short, probably less than 1 my (see Report on Site 134 in Chapter 15).

\section{Tectonic Mixing}

In two instances during the investigations of the Mediterranean DSDP cores, an abnormal stratigraphic succession involving inversion has been interpreted as the result of tectonic mixing. In both cases this was an alternative interpretation. The findings were from the eastern Mediterranean, where many lines of evidence indicate youthful compressional tectonics. Both findings are from the foot of a trench wall, where one would conceivably expect to find disturbances caused by active shearing and thrusting.

Site 127 (Ionian Basin) was located in the Hellenic Trench at the foot of the Northern wall. After penetrating a Pleistocene section over 400 meters thick, we found Lower Cretaceous limestones and dolomites (some $9 \mathrm{~m}$ thick) underlain by Upper Pliocene nannofossil-foraminiferal oozes. The contact between the Lower Cretaceous limestone and the pelagic ooze is well visible in Core 127-18-1. It is sharp, with some evidence of fracturing at the base (see appropriate illustrations in Chapter 9).

The occurrence of Lower Cretaceous limestones in this succession may be explained as either blocks fallen from the slope into Plio-Pleistocene unconsolidated sediments (syn-sedimentary sliding), or as chaotic jumbling due to tectonic mixing (mélange).

In order to examine these alternatives, two additional offset holes were drilled at the same location, both of them upslope from the original hole along a straight line traverse. A similar Pleistocene/Lower Cretaceous contact was then recorded at 167 meters and 78 meters below bottom, respectively, thus permitting us to define the geometry of the buried surface of the Upper Cretaceous limestone. We believe that no proof will be considered definitive by scientists with a skeptical approach to underthrusting. This buried surface, in fact, might well belong to an olistostrome.

The role of a paleontologist, in cases like this, is to critically analyse the evidence given by the fossils, in as objective a way as possible, without much speculation. With this approach, we may state that our findings are consistent with the hypothesis of underthrusting in the Hellenic Trench, though it cannot be proven.

Tectonic mixing has also been considered as a possible alternative explanation for the abnormal stratigraphic succession penetrated at Sites 129 and 129A, in the Levantine Basin. The hole was located in the Strabo Trench at the foot of the Strabo Mountains. The occurrence of a very specialized faunal assemblage indicating restricted marine conditions and a very late Miocene age under the fossiliferous sediments of Middle Miocene age is still very puzzling. Unlike the case of Site 127, poor core recovery unfortunately hampered a good visual impression of an unconformable contact.

Extended reworking, downhole contamination, and tectonic mixing have all been proposed as possible explanations for the stratigraphic superposition. Downhole contamination is objectively the weakest and least probable. Reworking is theoretically possible, but not very likely. Tectonic mixing, though not founded on clear evidence and being fairly speculative, is probably the best explanation at the present time. Further discussions on this subject may be found in the Site 129 report of Chapter 10.

\section{Zonations}

The only fossil groups for which biostratigraphic zonations could be applied are the planktonic foraminifera and calcareous nannofossils. Other microfossils present in the Mediterranean DSDP cores are as yet too scanty or too infrequently recorded to be suitable for the identification of useful biozones.

\section{Planktonic Foraminiferal Zonation}

PRE-PLIOCENE: Most of the sediments recovered from the Mediterranean are Pleistocene and/or Pliocene in age. Core recovery from older sediments was very poor so that only in the best cases were we able to arrive at the identification of a definite zone (see for instance the Globorotalia acostaensis-Globorotalia merotumida Zone of Banner and Blow (1965) in the lowermost part of the section penetrated at Site 121, Alboran Basin). Often we recognized only a stratigraphic interval corresponding to two or more foraminiferal zones (see, for instance the Serravellian, as identified in Site 129, Levantine Basin). In any case, the material recovered was unsuitable for detailed biostratigraphical investigations.

PLIOCENE: 'We concentrated our greatest attention on the Pliocene successions, which were ideally suited for this purpose. Two drilling sites were selected for continuous coring, both of them at locations free from intercalations of terrigenous sediments: the Tyrrhenian Site 132 and Site 125 in the Ionian Basin (crest of the Mediterranean Ridge). At the latter site, continuous coring was repeated twice, the core recovery of the first hole (125) having been judged insufficient for biostratigraphic investigations. The cores 
recovered from Site 125A thus offer an additional confirmation of the biostratigraphic succession.

Spot cores consisting of pelagic sediments sometimes associated with turbidites were taken at different locations in the western Mediterranean (namely, Site 121 in the Alboran Basin, Sites 122 and 123 in the Valencia Trough, and Sites 124 and 134 in the Balearic Basin). This supplementary material proved very useful for checking the new foraminiferal zonation as well as for testing its consistency with the nannofossil zonation. Reference is made to Chapter 47.1 of this volume for a definition of the various foraminiferal zones, the correlation of these zones with others based on tropical successions in different parts of the world as well as in the Mediterranean land sections, and lastly, the correlation with stratotypes of marine stages in Italy.

Detailed range charts were plotted for each Pliocene succession investigated, and only after completion of these documents was attention paid to the criteria for selecting the biostratigraphic events to be used for defining the biozones and to the choice of zonal markers.

The ranges of many taxa appeared to be limited, so that a number of combinations were possible. We considered the following points to have the highest priority:

1) The use, as zonal markers, only of taxa not involving taxonomical problems.

2) The use, as zonal markers, of fossils which do not appear to be significantly ecologically sensitive unless the ecologic control itself is related to a well-defined and isochronous paleogeographical event.

3) The selection of zonal boundaries in such a way that time is subdivided into parts as similar in duration as possible.

4) The use, in order to define zonal boundaries, of biostratigraphic events correlated with paleomagnetic stratigraphy, and apparently isochronous, at least as far as the Mediterranean Basin is concerned. The consistency of both the relative thickness of the various biozones, and the systematic non-overlapping correlation with nannofossil zones in the eight sections investigated (three of which were continuously cored) are considered strong arguments in favor of isochroneity.

The proposed zonation is the sum of one acme zone (ecologically controlled, but considered synchronous), two lineage zones (recognized on the basis of statistical studies) and three interval zones, based on a combination of ranges. Zones are named according to the internationally agreedupon rules recently defined by the IUGS Commission on Stratigraphy, Subcommission on Stratigraphic Classification (Circular n. 36, July 1971).

PLEISTOCENE: It is not possible to establish any zonation in the Pleistocene by means of planktonic foraminifera. Their distribution is essentially controlled by ecologic factors which we believe result mainly from changes in the temperature of the surface water layer within the photic zone. Other ecologic factors, such as stagnation, which are directly or indirectly related to the fluctuating climatic conditions which characterize the Pleistocene, also play an important role in the Mediterranean foraminiferal assemblages (see discussion of stagnation earlier in this chapter).
Ecologic factors and sedimentary processes are thus apparently much more important than time in controlling the distribution of planktonic foraminifera in the Pleistocene. Since all the changes we noticed are repeated in a number of cycles, they cannot be used to define an irreversible succession.

As a consequence, we used only one zone, the Globorotalia truncatulinoides Total-range-zone. It must be kept in mind that the range of $G$. truncatulinoides in the Mediterranean is much more restricted than the total range known for the taxon. In only one case (Core 4, Site 125) did we find the first occurrence of $G$. truncatulinoides where it was expected to be, and in most cases it appeared only later in the section. In these instances we used the Discoaster brouweri extinction horizon, to identify the lower boundary of the zone under discussion. This horizon occurs at about the same level, or just slightly above, as shown by a number of Mediterranean DSDP drilling sites.

Hays and Berggren (1971), after critically analysing all the datum planes used to identify the Pliocene/Pleistocene boundary in deep-sea sediments, concluded that the $G$. truncatulinoides datum appears to be most reliable. We agree with them. Further discussion of this argument may be found in the report on the Quaternary record of the Ionian Basin in Chapter 46.

\section{Nannofossil Zonation}

Dr. Herbert Stradner, the shipboard nannofossil specialist, has rather successfully applied Martini and Worsley's (1970) standard zonation to the drill cores obtained during the cruise. A number of his zonal identifications appear in the site reports of Chapters 2 through 15 . The comprehensive investigations of the entire cruise have resulted in the identification of three biostratigraphic zones in the Pleistocene sequences and seven zones in the Pliocene sequences.

It turns out that the resolution of nannofossil biostratigraphy is often higher than that based on planktonic foraminifera, particularly in the Pleistocene, where the nannofossils have apparently been less sensitive than foraminifera to ecologic changes. The combination of foraminiferal zones and nannofossil zones in the Pliocene gives a remarkably high resolution biostratigraphy of very good quality.

Some remarks follow, concerning our necessity to slightly modify their zonation, which in part was based on land sections, including the stratotypes of a number of classical European stages, and in part on deep-sea cores, including DSDP cores from Leg 7 in the Pacific Ocean.

PLIOCENE: According to Martini, the Ceratolithus tricorniculatus Zone should be entirely Miocene in age, and the Miocene/Pliocene boundary should fall in the lower part of the Ceratolithus rugosus Zone. However, this boundary, based on deep-sea successions, is inconsistent with new biostratigraphical evidence given by some stratotype land sections and by our own findings at Site 132 (Tyrrhenian Basin). We recall that the precise age assignment of the Ceratolithus tricorniculatus Zone has long been debated (see reports by S. Gartner and D. Bukry on DSDP Leg 2 also discussed in Cita, 1971b). According to our Mediterranean evidence, the Ceratolithus tricorniculatus 
Zone is neither entirely Miocene, as recorded by Martini and Worsley (1970), Martini (1971a), and Bukry (1971), nor does it straddle the Miocene/Pliocene boundary as assumed by Gartner (1969). In fact, our evidence shows it to be entirely Pliocene - an observation in agreement with Martini's (1971b) identifying it in the Trubi marls of Buonfornello, Sicily, (op. cit., p. 768).

The zonation used by D. Bukry for our cores (see Chapter 33), although different in part from Martini's, is entirely consistent with it. Bukry agrees that the Ceratolithus tricorniculatus Zone is Pliocene in age; furthermore he suggests that the section continuously cored in the Tyrrhenian Basin at Site 132 may be considered as a reference section for the Plio/Pleistocene of the Mediterranean area.

PLEISTOCENE: The application of Martini's zonation for the Pleistocene sequence in the Mediterranean cores is slightly more problematic than for the Pliocene sequences. For instance, Pseudoemiliania lacunosa (the extinction horizon of which is used to define the base of the Gephyrocapsa oceanica Zone) seems to range higher in the Mediterranean than in open oceans, and similar evidence has since been recorded by Martini and Muller (personal communication to the writer) in piston cores from the Mediterranean. Consequently, the Gephyrocapsa oceanica/ Pseudoemiliania lacunosa boundary is sometimes indicated with a dotted line and/or with a question mark on illustrations appearing in this volume. This boundary, as identified in the cores by H. Stradner, is also consistently higher than the lower boundary of the Gephyrocapsa oceanica Zone, as identified by Bukry, because of the different definition of the Gephyrocapsa oceanica Zone (see Chapters 42 and 33, respectively).

PRE-PLIOCENE: The identification of nannofossil zones in pre-Pliocene sediments was difficult in many cases, owing particularly to overcalcification of the discoasters. We point out the identification of the Discoaster quinqueramus Zone in Cores 21-2 and 22, Site 132, which belong to the evaporitic succession of Messinian age (see Site report). Up to the present time the nannofossil content of the type Messinian has been uncharted. However, because the Discoaster hamatus and $D$. calcaris zones have been documented in the type Tortonian (see Martini, 1971b) and since in deep-sea sequences the Discoaster quinqueramus Zone always lies between the Discoaster calcaris Zone and the Ceratolithus tricorniculatus Zone, it seems entirely logical to accept the presence of Discoaster quinqueramus as indicative of either late Tortonian or Messinian age.

\section{Correlation Between the Foraminiferal Zones and the Nannofossil Zones}

Correlations between the foraminiferal zones and the nannofossil zones as identified in the Tyrrhenian Basin (Site 132) are illustrated in Figure 5. On the right side one may see the location of the 22 cores considered, each one 9 meters long. Thus, the thickness of the various zones in the illustration is proportional to their in situ thickness and also approximately to their duration in time, since the rate of sedimentation was rather uniform in all the sections investigated.
The foraminiferal zones recognized in the Pliocene correspond generally to periods of time of equal duration in contrast to the nannofossil zones, which have variable durations. The shortest nannofossil zone is the Discoaster pentaradiatus Zone of the Upper Pliocene. With the rate of sedimentation calculated at $3.3 \mathrm{~cm} / 10^{3} \mathrm{y}$, and a thickness of only 0.5 meter, its duration is certainly less than 100,000 years.

This very short duration of the Discoaster pentaradiatus Zone is in agreement with the findings of Martini on Leg 7 of the DSDP in the equatorial Pacific. In addition, the Discoaster asymmetricus Zone is fairly short, probably lasting some 300,000 years. It turns out that this zone, as defined by Martini and Worsley (1970), and used by Martini (1971a) and Stradner (this report) but, unfortunately not used by Bukry (1971), is a very suitable means for separating the Lower and the Upper Pliocene. In fact the extinction horizon of Globorotalia margaritae (group), which has been used to precisely mark the Lower/Upper boundary (e.g. see discussions in Chapter 47.1), conveniently and consistently falls within the Discoaster asymmetricus Zone at all the drilling sites.

The correlations discussed concern not only Site 132 in the Tyrrhenian Basin, but are consistent for Sites 125, $125 \mathrm{~A}$, cored continuously in the Ionian Basin, Site 121 (Alboran Basin), Sites 122 and 123 (Valencia Trough) and Sites 124 and 134 (Balearic Basin).

\section{Differences Between Atlantic and Mediterranean Faunas}

Our findings add little, if anything to what is known from the literature regarding pre-late Miocene (Messinian) times. Since the problem of the affinities and differences between Mediterranean and tropical Atlantic foraminiferal assemblages, including problems of biostratigraphic correlation between standard zonations and European stages, has been debated at such length that it is not worthwhile treating it here, inasmuch as we had so little material to investigate, and none of it was better than material from land-based sections. Reference is made to Cita and Blow (1969), a joint paper by representatives of two different schools, which tries to settle and/or clarify a number of controversial points.

Nevertheless, a real addition to our knowledge and understanding does derive from our findings within the late Miocene evaporite strata, recorded in all the deep basins of the Mediterranean, of a sharp sedimentary and faunistic break occurring at the Miocene/Pliocene boundary and of deep-sea, oceanic-type Pliocene succession.

Sedimentation during the latest part of the Miocene was so strongly affected by quite unusual paleogeographic conditions (described in Chapter 43) that a comparison between Mediterranean and Atlantic faunas cannot even be attempted. Intercalated in the evaporites, we found assemblages of brackish-water diatoms (Core 125-15), of isohaline ostracods and benthic foraminifera (Core 129 A-2, CC), and of marine faunas, dwarfed and scattered (at Sites 132, 134 and 124). All the occurrences indicate ecologic conditions highly variable in time and space which are exclusive to the Mediterranean domain.

Brackish-water faunas and floras and marine faunas are recorded from layers alternating with true evaporites, which 


\begin{tabular}{|c|c|c|c|}
\hline AGE & FORAMINIFERAL ZONES & NANNOFOSSIL ZONES & 岩崫 \\
\hline \multirow{7}{*}{ 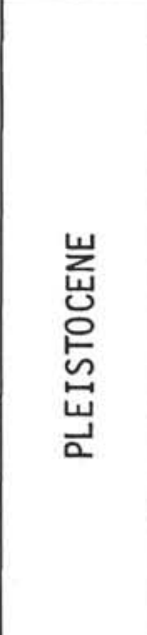 } & \multirow{7}{*}{$\begin{array}{c}\text { Globorotalia truncatulinoides } \\
\text { Total-range-zone }\end{array}$} & \multirow{2}{*}{ Emiliania huxleyi Zone } & 1 \\
\hline & & & 2 \\
\hline & & \multirow{2}{*}{ Gephyrocapsa oceanica Zone } & 3 \\
\hline & & & 4 \\
\hline & & \multirow{3}{*}{ Pseudomiliania Zacunosa Zone } & 5 \\
\hline & & & 6 \\
\hline & & & 7 \\
\hline \multirow{5}{*}{ 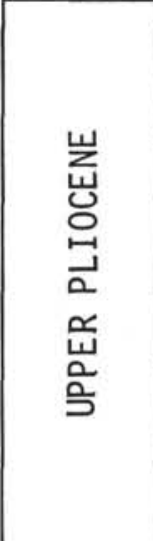 } & $\begin{array}{c}\text { Globoratalia inflate } \\
\text { Interval-zone }\end{array}$ & Discoaster brouweri Zone & 9 \\
\hline & \multirow{3}{*}{$\begin{array}{c}\text { Globigerinoides obliquus } \\
\text { extremus } \\
\text { Interval-zone }\end{array}$} & Discoaster pentaradiatus Zone & 10 \\
\hline & & \multirow{2}{*}{ Discoaster surculus Zone } & 11 \\
\hline & & & 12 \\
\hline & \multirow[t]{2}{*}{$\begin{array}{c}\text { Spheroidinellopsis subdehiscens } \\
\text { Interval-zone }\end{array}$} & $\begin{array}{c}\text { Reticulofenestra } \\
\text { pseudoumbilica Zone }\end{array}$ & 13 \\
\hline \multirow{8}{*}{ 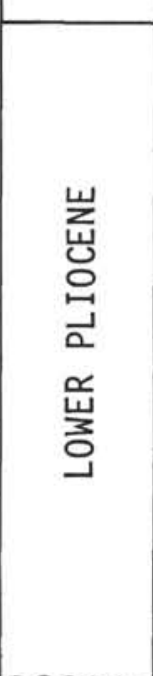 } & & Discoaster asymmetricus Zone & 14 \\
\hline & \multirow{3}{*}{$\begin{array}{c}\text { Globorotalia margaritae evoluta } \\
\text { Lineage-zone }\end{array}$} & \multirow{2}{*}{ Ceratolithus mugosus Zone } & 15 \\
\hline & & & 16 \\
\hline & & \multirow{5}{*}{$\begin{array}{l}\text { Ceratolithus } \\
\text { tricorniculatus Zone }\end{array}$} & 17 \\
\hline & \multirow{2}{*}{$\begin{array}{c}\text { Globorotalia margaritae } \\
\text { margaritae } \\
\text { Lineage-zone }\end{array}$} & & 18 \\
\hline & & & 19 \\
\hline & Spheroidinellopsis & & 20 \\
\hline & Acme-zone & & 21 \\
\hline $\begin{array}{l}\text { LATE } \\
\text { MIOCENE }\end{array}$ & Globorotalia plesiotumida Zone & Discoaster quinqueramus Zone & 22 \\
\hline
\end{tabular}

Figure 5. Correlation between foraminiferal zones and nannofossil zones in the Neogene successions penetrated in the Tyrrhenian Basin at Site 132. 
are quite barren of any fossil remains. Since we were able to demonstrate that deposition of evaporites occurred throughout the whole Mediterranean, it seems improbable that a preevaporitic fauna could have survived all the rigors of a desiccated sea. ${ }^{4}$

According to our model every fossiliferous layer intercalated in the evaporites which yields marine faunas and floras, including foraminifera, indicates an inflow of marine water into a (partly?) desiccated Mediterranean from the open Atlantic Ocean. This is based on our conclusion that it is highly unlikely assemblages of marine fossils could have evolved locally from Mediterranean ancestors, since foraminifera, unlike ostracods, would not be expected to have survived periods of desiccation and strong variations in salinity.

Since completion of the cruise, the writer has had an opportunity to discuss these occurrences of intercalated marine faunas with stratigraphers working in the Mediterranean area, who believe that they have found continuous marine sequences straddling the Miocene/Pliocene boundary in southern Spain, in Italy, in Crete, and in Algeria. It must be kept in mind that paleontology is not a proper tool for proving this proposed continuity, since the entire "crisis of salinity" occupies only a single foraminiferal (N 17) and a single nannofossil (NN 11) zone (see discussion of sedimentation rates earlier in this chapter). Therefore, since similar or identical faunas may be found which belong to different desiccation cycles, but to the same biozone, it may be possible to infer a continuous sedimentation (no biostratigraphic gap) during what may have been an interval of repeated desiccations and inundations, involving only brief incursions from the Atlantic. Only sedimentological investigations especially oriented to checking the assumed continuity of marine sedimentation in land outcrops can establish or refute this point.

For the evaluation of the paleoclimatic conditions occurring during the crisis of salinity, we cannot use just our drilling data, because they are insufficient. A rich flora from the Tripoli Formation ${ }^{5}$ of Messinian Age is commonly associated with evaporites, particularly at Gabbro, Tuscany (Berger, 1958), where it provides interesting paleoclimatic indications for the Tyrrhenian area. More than 100 species have been identified, mostly of terrestrial plants. Species providing an indication of the climate at that time, although rare, include Lauroceae which is strongly suggestive of a hot and humid forest setting. Also present are species which indicate a forest of relatively dry and temperate conditions, and even Leguminosae and other plants which indicate savanna or steppe-like environments.

Since one of the most conspicuous components of the basins of reduced salinity is the gastropod Melanopsis, which indicates warm-water conditions (Ruggieri, 1967),

\footnotetext{
${ }^{4}$ For instance see Ruggieri (1967, p. 286) who, based on the study of Tethyan faunas, concluded long before the deep-sea drilling cruise that: - "It is possible that the marine Miocene fauna was able to survive in some parts of the Mediterranean, but it seems much more likely that it was totally destroyed by adverse environmental conditions."

5 "Tripoli" is identified in Italy as a diatomaceous marl, often rich in organic matter. It occurs characteristically in the lowermost part of the "Formazione gessoso solfifera" (see Ogniben, 1957).
}

we would infer that the general climate might satisfactorily be classified as a subtropical type with both arid and humid environments developed in local basins or at different altitudes.

We note also that palynological investigations by Bertolani Marchetti (1968) on the "Formazione gessososolfifera" in Emily and in Sicily were interpreted to indicate some periods of cold climates in Messinian times coincident with the evaporitic epoch. The occurrence of left-coiling populations of Globigerina pachyderma in the Messinian of Italy has been noted by Jenkins (1967), but this finding is not considered by the writer as irrefutable evidence of a colder climate as was assumed to be the case by Bandy et al. (1971).

It results from the above discussion that we have evidence, both from the literature and from our findings, of extremely variable conditions of temperature, humidity, and salinity, and we have also during late Miocene times, some evidence, in part contradictory, of cold temperatures.

In our desiccation model (see Chapter 43) we propose glacio-eustatically controlled changes in the sea level as a possible alternative to erosional processes for explaining the cyclically repeated incursions of Atlantic water into the Mediterranean. However, the evidence of cooler climate involving high latitude glaciation in the later parts of the Miocene seems to be more adequately documented in the southern than in the northern hemisphere (Bandy et al., 1971).

The Lower Pliocene foraminiferal fauna of the Mediterranean is less diverse and "colder" than the North Atlantic fauna, at comparable latitude. The oldest Pliocene sediments cored from the Mediterranean are those of Cores 20 and 21 (pars), Site 132. They belong to the Sphaeroidinellopsis Acme Zone and to the Ceratolithus tricorniculatus Zone (nannofossil). The foraminiferal fauna is dominated by Sphaeroidinellopsis, is very restricted in number of taxa, and is practically devoid of benthic organisms, including not only the benthonic foraminifera but ostracods, echinoide spines, etc. The absence of benthic life, mainly in Sicily at the beginning of the Pliocene transgression is already known from the work of Ruggieri (1967), who found that only later was a benthic fauna reestablished. The significance of the lack of benthic species in the earliest marine sediments is discussed by Benson (1971), who postulates a rapid marine transgression after the salinity rise and a subsequent time delay before marine populations reacquired the previously sterile sea bed.

As far as the North Atlantic environments at that time are concerned, the writer has had some recent experience with both the faunas of the Cape Verde Region - DSDP Site 12 (Cita, 1971b), and Gorringe Bank - Site 120 of Leg 13. Although the foraminiferal faunas of Cape Verde cannot be directly compared with those of our Mediterranean sites because of differences in latitude of 15 degrees to 20 degrees, we may quite adequately compare our Mediterranean sites with Site 120 located just to the west of the Straits of Gibraltar. Here we recovered a small amount of Lower Pliocene pelagic sediment rich in foraminifera. In addition to Globorotalia margaritae, the most conspicuous component and the only "keeled" Globorotalia of the Mediterranean Lower Pliocene, we found $G$. 
miozea, G. cibaoensis, and G. menardii, which we never recorded in the Mediterranean, though they are known there from preevaporitic Miocene formations. ${ }^{6}$ Other species recorded from the Mediterranean Miocene and known to range into the Pliocene in the Atlantic include Globoquadrina altispira, G. dehiscens, G. larmeui, and Globigerina nepenthes. Among these, only Globoquadrina altispira has been found in the Mediterranean Pliocene. For an explanation of why certain species apparently never migrated back into the Mediterranean, we must suppose some kind of an ecological or physical barrier at Gibraltar.

For example, Benson (1971) believes that during Pliocene times the entire circulation pattern of the Mediterranean was reversed with respect to the present day situation, with surface water flowing out of the Mediterranean and bottom water flowing into it. The water entering, being of North Atlantic Deep-Water origin, could be responsible for a deep, oceanic type circulation during Lower Pliocene times that not only could explain the numerous erosional unconformities in the western Mediterranean Basin, but might also explain the "cold" character of the Mediterranean versus Atlantic faunas. ${ }^{\text {? }}$

In summary, we have presented evidence which suggests the following history of oceanographic communications between the Mediterranean and the North Atlantic.

1) Preevaporitic Middle and Late Miocene times are characterized by similar benthic and planktonic assemblages suggestive of free exchange and unhindered reproduction within the Mediterranean basins. Benthic faunas are lacking during the Serravallian in the eastern basins, suggestive of local bottom water stagnation there.

2) During the Messinian "salinity crises" there is only limited reproduction within the desiccated Mediterranean basins which results in dwarfed tests. Occasional floodings from the Atlantic were able to transport "healthy" welldeveloped planktonic passengers destined to be preserved, in otherwise barren strata. The same barren sequences in the evaporite formation suggest extensive periods when the entire deep-basin part of the Mediterranean was sterile, while the occasional intermittent development of brackishwater species is considered excellent evidence of moments of a total isolation of the Mediterranean sea from the open marine reservoir of the North Atlantic.

3) In the post-evaporitic open marine environment of the Lower Pliocene, only selected species from the Atlantic were able to reenter and repopulate the eastern and western Mediterranean basins, thus indicating some sort of a physical or ecological barrier at Gibraltar which apparently persists up to now. The discovery of psychrosphaeric ostracods (see Chapter 36.1) in the Lower Pliocene pelagic oozes of Sites 132 and 134 is considered good documentation that immediately following the Late Miocene terminal flooding a deep passage was established at the Gibraltar

\footnotetext{
${ }^{6}$ Similar findings of G. miozea, G. cibaoensis and G. Menardii, have been made by J. P. Beckmann (personal communication) to the south at Site 135, across the Horseshoe Abyssal Plain from Site 120 .

${ }^{7}$ See also the oxygen isotope measurements on both the benthonic and planktonic foraminifera of the Lower Pliocene of Site 132 reported in Chapter 30.4 .
}

Portal, allowing cold North Atlantic Deep Water to penetrate the western basins of the Mediterranean. The gradual disappearance of these ostracods in the early Pleistocene is interpreted as evidence of a progressive shallowing of this portal which in turn choked off a deep thermo-haline circulation of North Atlantic origin. This conclusion is collaborated by the lack of depositional hiatuses and erosional surfaces in the younger strata of the Pleistocene sequences, both in the recovered drill cores and in the subbottom reflection profiles.

\section{REFERENCES}

Bandy, O. L., Casey, R. E. and Wright, R. C., 1971. Late Neogene planktonic zonation, magnetic reversals, and radiometric dates, Antarctic to the Tropics. Antarctic Res. Series. Amer. Geophys. Union. 15, 1.

Banner, F. T. and Blow, W. H., 1965. Progress in planktonic foraminiferal biostratigraphy of the Neogene. Nature. 204 (5016), 1164.

Benson, R. H., 1971. Ostracodes as indicators of threshold depth in the Mediterranean during the Pliocene. Proc. VII Intern. Congr. Sediment., Heidelberg. (in press).

Berger, W., 1958. Untersuchungen an der obermiozänen (sarmatischen) Flora von Gabbro (Monti Livornesi) in der Toskana. Palaeontographia Italica. LI, 1.

Berggren, W. A., 1971. Multiple phylogenetic zonations of the Cenozoic based on planktonic foraminifera. Proc. II Plankt. Conference, Rome. 1, 41.

Bertolani, Marchetti, D., 1968. Vegetational features in sediments of Messinian "Formazione gessoso-solfifera" in Emilia and Sicily (Italy) and paleoclimatic problems. Intern. Geol. Congr., 23rd Sess. Abstract. 271.

Blow, W. H., 1969. Late Middle Eocene to Recent planktonic foraminiferal biostratigraphy. Proc. I Intern. Conf. Plankt. Organisms. Ed. Brill. 1, 199.

Bradshaw, J. S., 1961. Laboratory experiments on the ecology of foraminifera. Contributions from the Cushman Foundation for Foraminiferal Research. 12, 87.

Bukry, D., 1970. Coccolith age determinations, Leg 2 DSDP. In Peterson, M. N. A., Edgar, N. T. et al., 1970. Initial Reports of the Deep Sea Drilling Project, Volume II. Washington (U.S. Government Printing Office). 349. , 1971. Coccolith Stratigraphy, Leg 7 Deep Sea Drilling Project. In Winterer, E. L., Riedel, W. R. et al., 1971. Initial Reports of the Deep Sea Drilling Project, Volume VII. Washington (U.S. Government Printing Office). 1513.

Castellarin, A., 1962. Risultati preliminari sulla geologia dell 'Altipiano di Cei (Trentino meridionale). Boll. Soc. Geol. Ital. 81 (4), 363.

Catalano, R., and Sprovieri, R., 1969. Stratigrafiae micropaleontologia dell 'intervallo tripolaceo di Torrente Rossi (Enna). Atti Acc. Gioenia Sc. Nat., Catania. ser. 7. 1,513 .

, 1971. Biostratigrafia di alcune serie saheliane (Messiniano inferiore) in Sicilia. Proc. II Plankt. Conference, Roma. 1, 211.

Chumakov, I. S., 1971. Geological history of the Mediterranean at the end of the Miocene-beginning of the Pliocene (according to new data). Abstract Proc. Acad. USSR Geol., Moscow.

Cita, M. B, 1965. Jurassic, Cretaceous and Tertiary microfacies from the Southern Alps (Northern Italy). Ed. Brill, Leiden, 1. 
1971a. Paleoenvironmental aspects of DSDP Legs I-IV. Proc. II Plankt. Conference, Roma. 1, 251.

, 1971b. Biostratigraphy, chronostratigraphy and paleoenvironment of the Pliocene of Cape Verde (North Atlantic). Rev. Micropal. 14 (5), 17.

Cita, M. B. and Blow, W. H., 1969. The biostratigraphy of the Langhian, Serravallian and Tortonian stages in the type-sections in Italy. Riv. Ital. Paleont. 75 (3), 549.

Cita, M. B. and Ciaranfi, N., 1971. Evidence of climatic changes in deep-sea Pliocene deposits from the Mediterranean (JOIDES-DSDP cores). Proc. IV Congr. Neog. Strat. Lyon. (in press).

Cita, M. B., Premoli Silva, I. and Rossi, R., 1965. Foraminiferi planctonici del Tortoniano-tipo. Riv. Ital. Paleont. 71 (1), 217.

Colalongo, M. L., 1970. Appunti biostratigrafici sul Messiniano. Giorn. Geol. ser. 2. 36 (2), 515.

Colom, G., 1967. Sur l'interprétation des sédiments profonds de la zone géosynclinale baléarique et subbétique (Espagne). Paleogeogr., Paleoclim., Paleoecol. 3, 299.

d'Onofrio, S., 1966. I foraminiferi del neostratotipo del Messiniano. Giorn. Geol. ser. 2. 32 (2), 409.

Fairbridge, R. W., 1966. The Encyclopedia of Oceanography. Reinhold Publ. Comp., 1.

Freudenthal, T., 1969. Stratigraphy of Neogene deposits in the Khania Province, Crete, with special reference to foraminifera of the family Planorbulinidae and the genus Heterostegina. Utrecht Micropal. Bull. No. 1, 1.

Gartner, S., 1969. Correlation of Neogene planktonic foraminifer and calcareous nannoplankton zones. Trans. Gulf Coast Assoc. Geol. Soc. 19, 585.

Hays, J. D. and Berggren, W. A., 1971. Quaternary boundaries and correlations. The Micropaleontology of Oceans. Cambridge, 669.

Hays, J. D., Saito, T., Opdyke, N. D., and Burkle, L. M., 1969. Pliocene-Pleistocene sediments of the Equatorial Pacific; their paleomagnetic, biostratigraphic and climatic record. Bull. Geol. Soc. Amer., 80, 1481.

Holmes, A., 1965. Principles of Physical Geology. T. Nelson Ltd., London, 1.

INQUA Congress, 1965. Section of Le Castella, Calabria

Jenkins, D. G., 1967. Recent Distribution, Origin and Coiling Ratio Change in Globorotalia pachyderma (Ehrenberg). Micropaleont. 52 (236), 217.

Jenkyns, H. C., 1970. The Jurassic of Western Sicily. In Geology and History of Sicily. Petrol. Explor. Soc. 245.

Kerdany, F. B., 1968. Note on the planktonic zonation of the Miocene in the Gulf of Suez Region U.A.R. Giorn. Geol. 35 (3), 157.

Malaroda, R., 1962. Gli hard-grounds al limite tra Cretaceo ed Eocene nei Lessini occidentali. Mem. Soc. Geol. Ital. 3, 108 .
Martini, E., 1971a. Neogene silicoflagellates from the Equatorial Pacific. In Winterer, E. L., Riedel, W. R. et al., 1971. Initial Reports of the Deep Sea Drilling Project, Volume VII. Washington (U.S. Government Printing Office).

1971b. Standard Tertiary and Quaternary calcareous nannoplankton zonation. Proc. II Plankt. Conference, Roma. 2, 739.

Martini, E. and Worsley, T., 1970. Standard Neogene calcareous nannoplankton Zonation. Nature. 225 (5229), 289.

Maxwell, A. E. et al., 1970. Initial Reports of the Deep Sea Drilling Project, Volume III. Washington (U.S. Government Printing Office). 1.

Mazzola, G., 1971. Les foraminifères planctoniques du Mio-Pliocène de 1 'Algérie nord-occidentale. Proc. II Plankt. Conference, Roma. 2, 787.

Ogniben, L., 1957. Petrografia della serie solfifera siciliana e considerazioni geologiche relative. Mem. Descr. Carta Geol. Ital. 33, 1.

Olausson, E., 1961. Studies of deep-sea cores. Rept. Swedish Deep-Sea Exped. 1947/48. VIII, 337.

Perch-Nielson, C., 1972. Remarks on Late Cretaceous to Pleistocene coccoliths from the North Atlantic. In Laughton, A. S., Berggren, W. A. et al. (1972). Initial Reports of the Deep Sea Drilling Project, Volume XII. Washington (U.S. Government Printing Office).

Premoli, Silva I. and Luterbacher, H. P., 1966. The Cretaceous-Tertiary boundary in the Southern Alps. Riv. Ital. Paleont. 72 (4), 1.

Richter-Bernburg, G., 1950. Sur Frage der absoluten Geschwindigkeit geologischer Vorgänge. Naturwiss. 37,1 .

Ruggieri, G., 1967. The Miocene and later evolution of the Mediterranean Sea. Aspects of the Tethyan Biogeography. Systematic Assoc. Publ. No. 7, 283.

Ruggieri, G., Torre, G., Moroni, A. M. and Aruta, L., 1969. Miocene superiore (Saheliano) nei dintorni di Bonfornello (Palermo). Atti Acc. Gioenia Sc. Nat. Catania. ser. 7. 1, 175.

Ryan, W. B. F., 1971. The Stratigraphy of the Eastern Mediterranean. Proc. VII Intern. Congr. Sediment. Heidelberg. (in press).

Theyer, F., 1971. Benthic foraminifera: bathymetric patterns of calcareous and arenaceous assemblages. Nature Physical Sciences. 229, 207.

Trejo, M., 1960. La Familia Nannoconidae y su alcance estratigrafico en America (Ptotozoa incertae sedis). Bol. Asoc. Mex. Geol. Petrol. 12 (fasc. 1-2), 259.

Turner, W. M., 1971. The Miocene-Pliocene boundary of Western Cyprus. Proc. V Congr. CMNS, Lyon. (in press). 


\section{PLATE 1}

Figure 1 Pyrite crystals from the pyrite marl of the Middle Miocene cored in the Strabo Trench. Core DSDP $129 \mathrm{~B}-1, \mathrm{CC} \times 252$.

Figure 2 Cyprideis pannonica (Mehes). Side view of a left valve, X 123. DSDP Core 129 A-2, CC. Late Miocene (Messinian) of the Strabo Trench. Cyprideis pannonica is the most conspicuous component of an oligotypical assemblage also yielding Ammonia beccarii tepida in abundance. Their associations indicate, according to Dr. A. Decima, a salinity of 20 to 30 percent. The genus Cyprideis prefers brackish (meso-polyhaline) environment.

Figure 3 Cyprideis pannonica (Mehes.) Dorsal view, $\times 105$. DSDP Core 129 A-2, CC. Upper Miocene (Messinian) of the Strabo Trench. The lower valve is the left one, which by definition is larger than the right one and overlaps it. Well visible are the evenly spaced pores, on the very smooth surface. 
PLATE 1
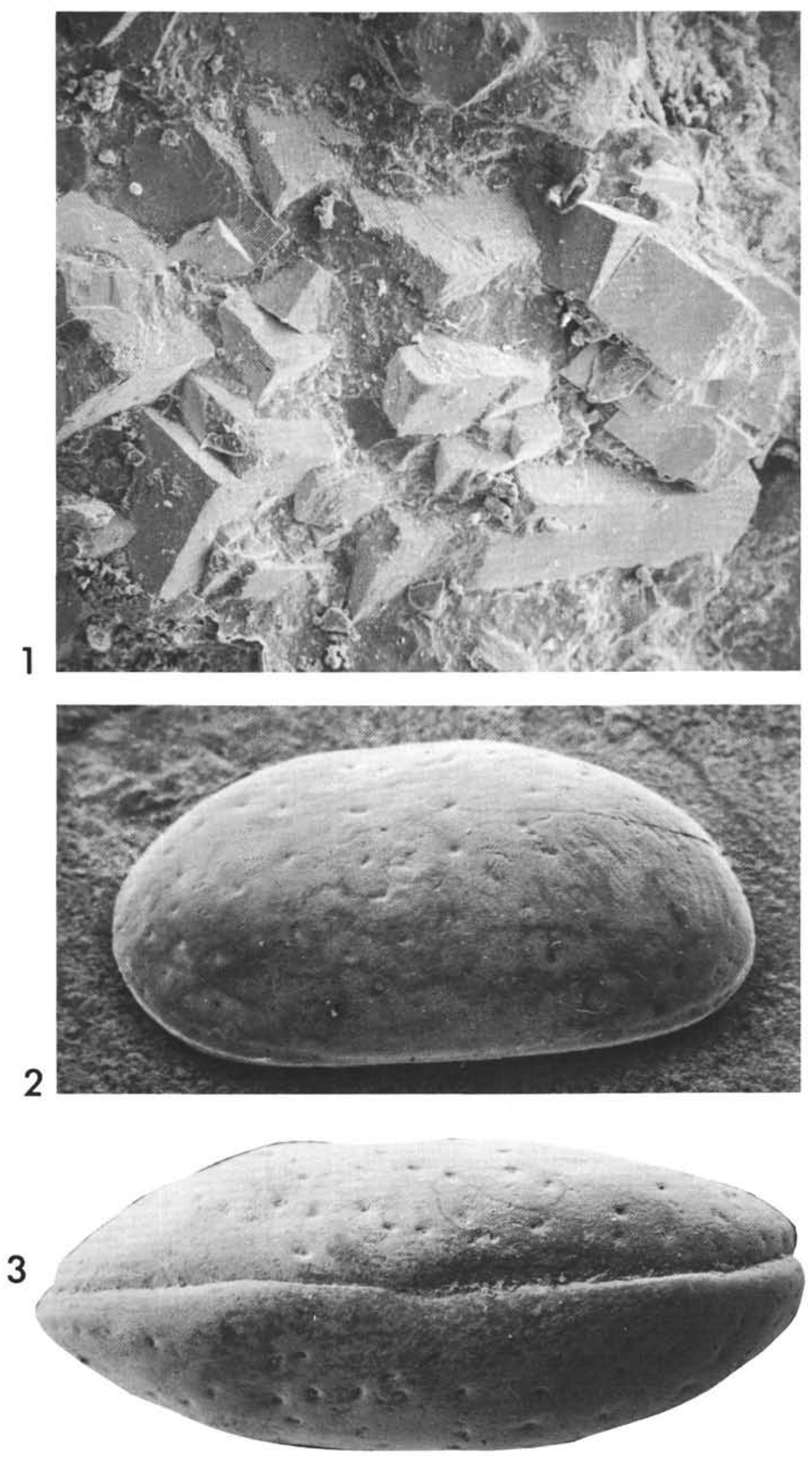


\section{PLATE 2}

Figure 1 A part of the sediment fraction greater than 173 microns (sieved) of DSDP Core 132-21-2, 0-2 cm, showing that (a) the sand-size fraction is entirely organogenic, (b) it consists of foraminiferal shells, most of which are broken, and (c) all the foraminifera are planktonic, but only a few are recognizable at a species level.

Figure 2 The same sample showing evidence of erosion on the external surface of some tests.

Figure 3

As above.

Figure 4 A close up enlargement showing the internal surface of a foraminiferal test (probably Orbulina universa d'Orbigny). No evidence of corrosion is visible on the internal side, thus excluding that fragmentation is originated by solution because of deposition near the Carbonate Compensation Depth. The sample illustrated is referred to the Sphaeriodinellopsis Acme zone (lowermost part of the Lower Pliocene). It lies some $60 \mathrm{~cm}$ above the Miocene/Pliocene contact. The sediment is dark red in color. Fragmentation and erosion of the foraminiferal tests are interpreted as being related to the sudden deep-sea transgression extending instantaneously over a desiccated basin. 
PLATE 2

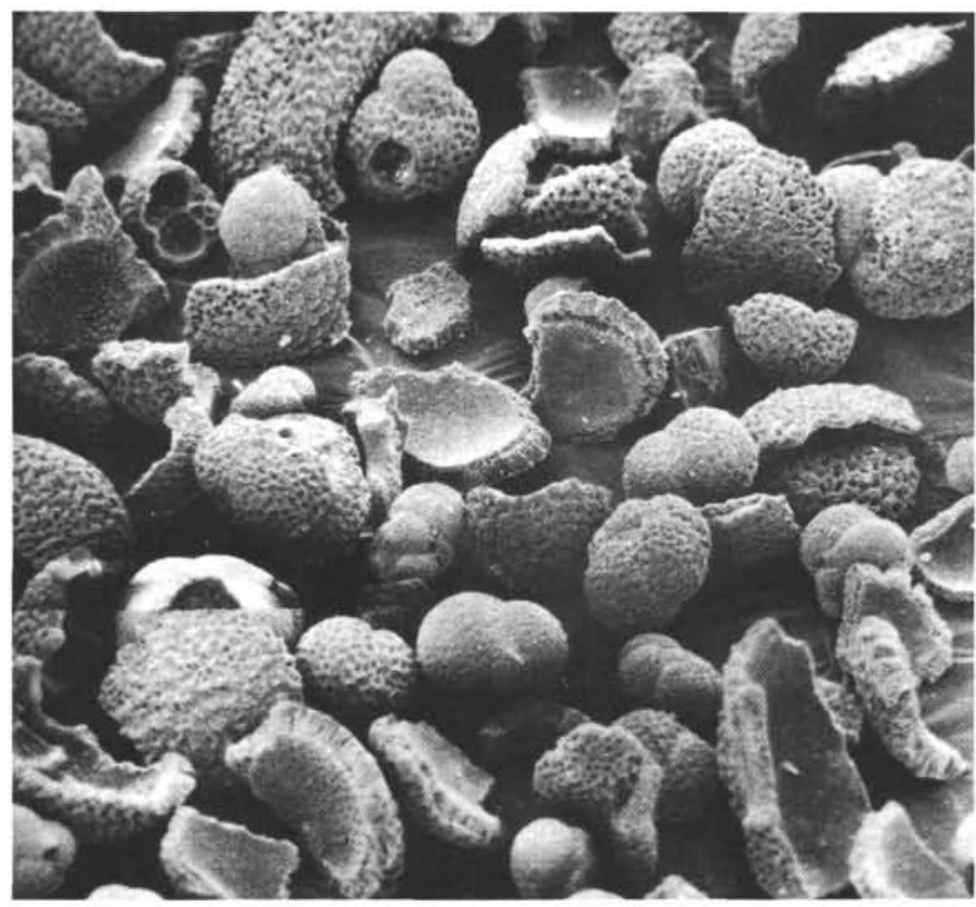

1
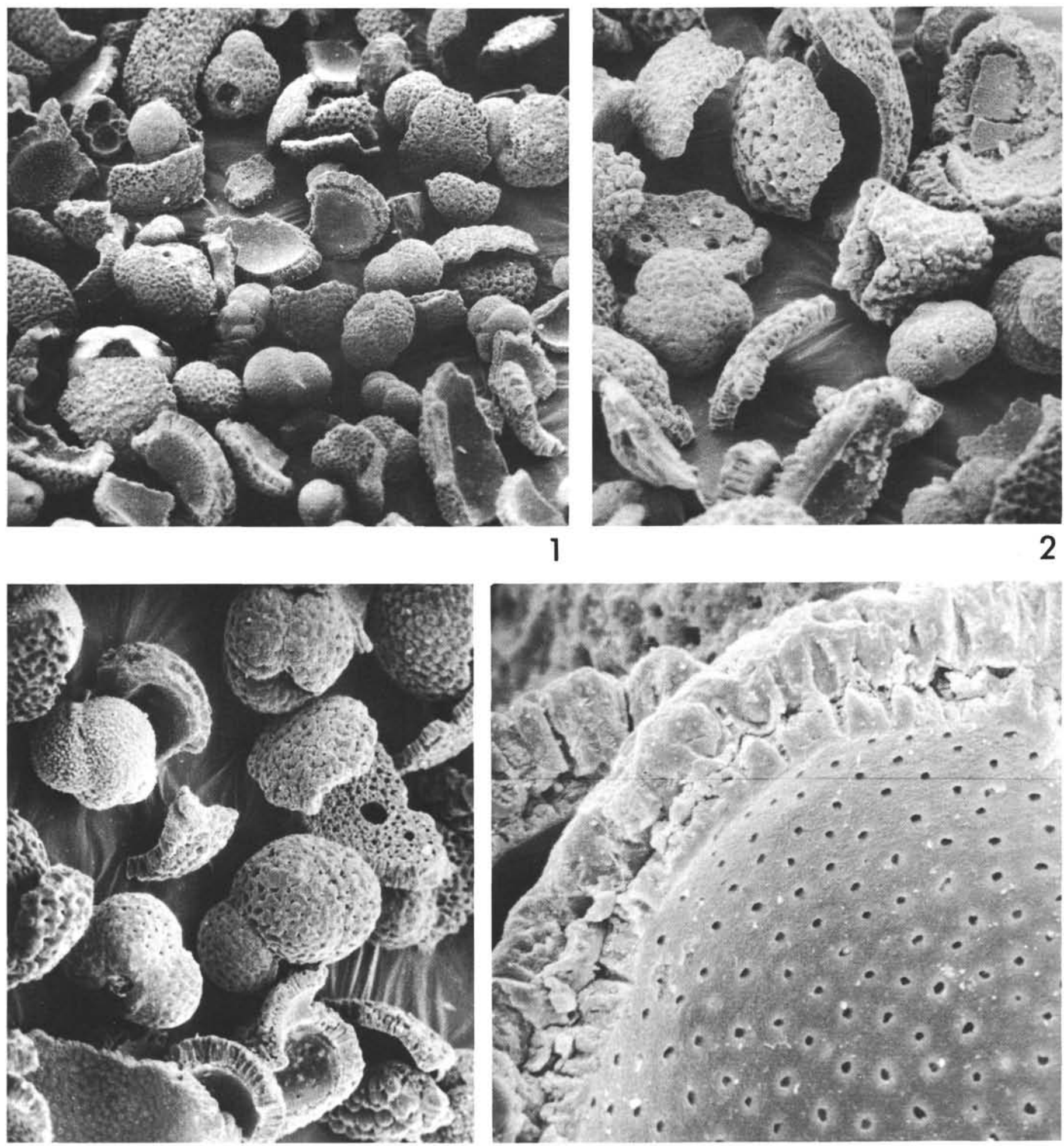


\section{PLATE 3}

All the samples illustrated are from DSDP Core 134E, Sidewall Core No. $1(-199 \mathrm{~m})$, which core the Pliocene/Pleistocene boundary at an unconformable contact associated with mineralized crusts (hardground).

Figure $1 \quad$ Globorotalia truncatulinoides (d'Orbigny). $\times 80$. Spiral view of a left-coiling specimen from the (unconsolidated) sediment immediately overlying the hardground illustrated in Figures 4 to 6 .

Figure 2 Globorotalia truncatulinoides pachyteca Blow. X 100. Spiral (slightly oblique) view of a right-coiling specimen.

Figure 3 Globigerina eggeri Rhumbler. $\times 100$. Spiral view. Specimens illustrated in Figures 1 to 3 do now show any trace of mineralization, however specimens with iron spots are visible in the sand-size fraction of the sediment.

Figure 4 A fragment of the actual mineralized crust cored at Site $134 \mathrm{E} \times 95$. Tests and casts of planktonic foraminifera are clearly visible. The thickness of the mineralized crusts is usually less than $1 \mathrm{~mm}$. The crusts are present in the sediment as fragments, the largest of which are about $1 \mathrm{~cm}$ in size. The iron crusts were probably continuous prior to the drilling and coring operations.

Figure 5 Another fragment of the fossiliferous, mineralized crust, $\times 85$.

Figure 6 An enlarged detail of Figure 5 depicting the outline of a replaced foraminiferal test. $\times 430$. 
PLATE 3

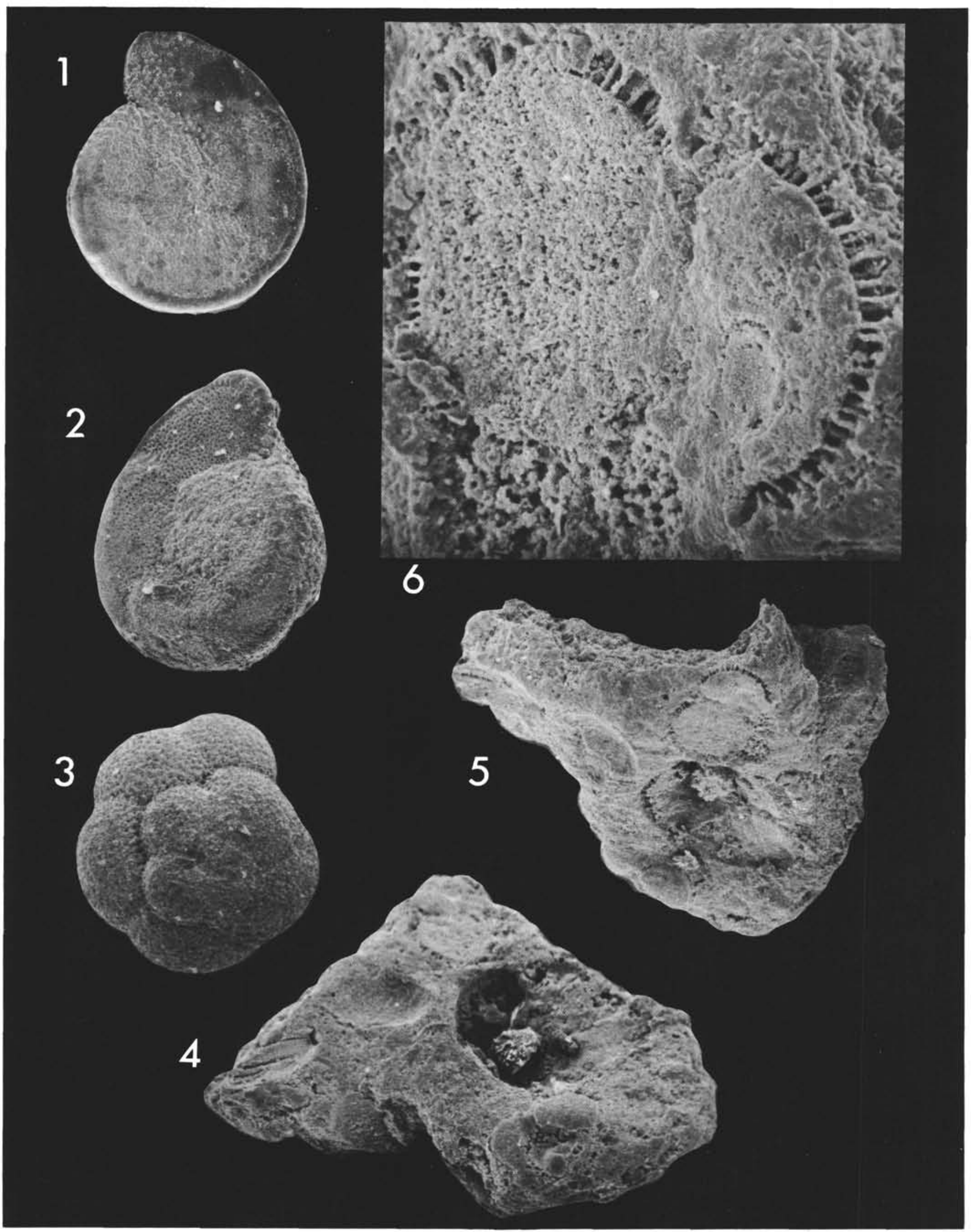




\section{PLATE 4}

Figure 1 Photograph of a thin section of an artificial agglomerate obtained with the sediment fraction greater than $63 \mu$ from Sidewall Core No. $1(-199 \mathrm{~m})$ of Site 134E (Balearic Abyssal Plain). The sediment is unconsolidated, and yields two mutually exclusive foraminiferal assemblages, referred to the Globorotalia truncatulinoides Total-range-zone (middle part) of Pleistocene age, and the Globigerinoides obliquus extremus Interval-Zone of the Upper Pliocene, respectively. Mineralized iron-crusts are present, containing planktonic foraminifera some of which keep their original calcitic test, while some are preserved only as casts. Such a mineralized crust is visible in the lower left corner, containing a test of Globorotalia. Other tests partly filled, or encrusted with iron concretions, are visible. $\times 50$.

Figures 2-3. These are sterio-scanning micrographs of mineralized crusts. Figure $2 \times 50$. Figure $3 \times 400$. The foraminiferal test has been destroyed. Tiny placoliths are visible at the upper left. 


\section{PLATE 4}
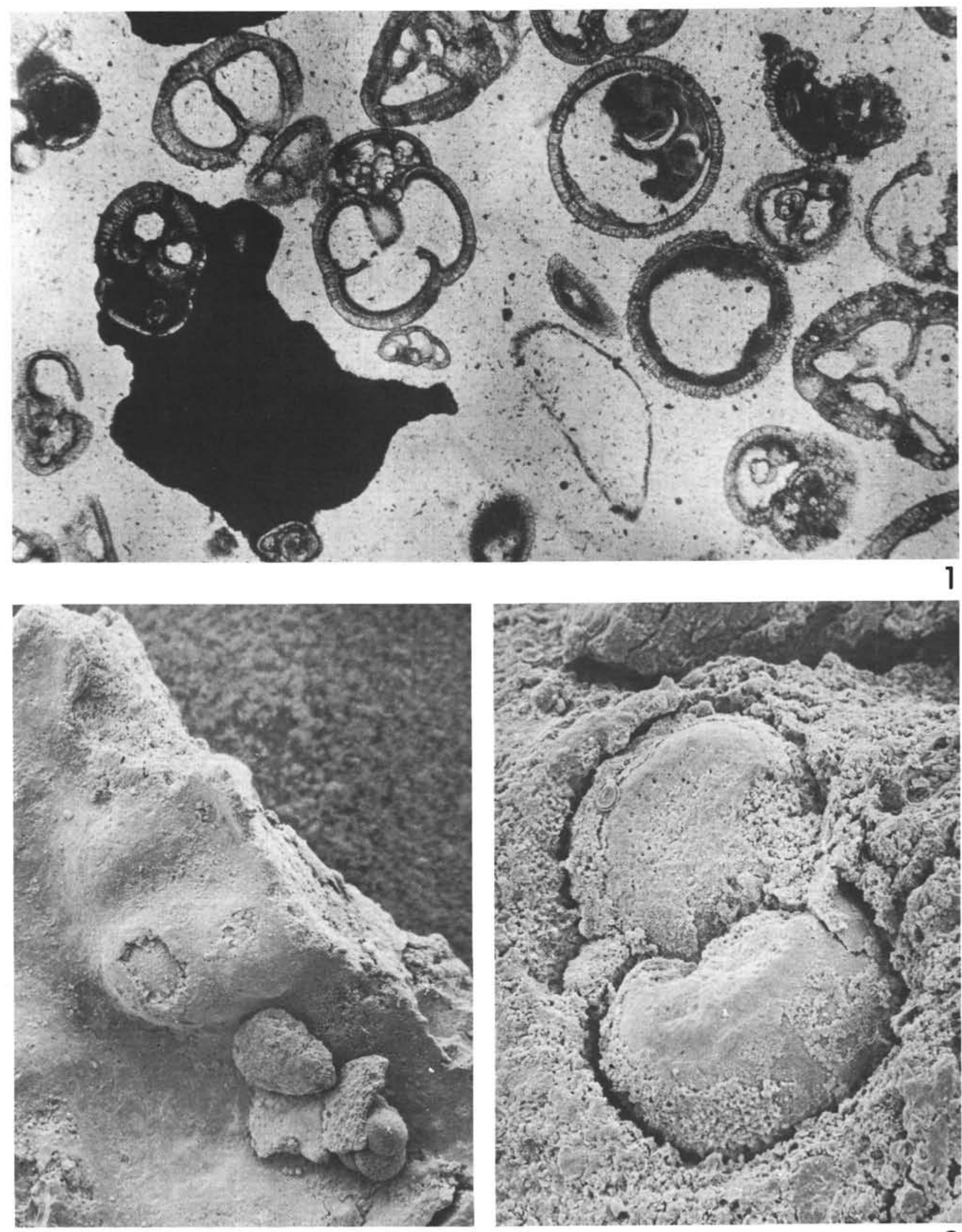